\title{
Review of the ammonite genus Pseudokossmaticeras Spath, 1922 from the uppermost Campanian-lower Maastrichtian in Bulgaria
}

\author{
Docho Dochev ${ }^{1}$, Lubomir Metodiev ${ }^{2}$ \\ ${ }^{1}$ Department of Geology, Palaeontology and Fossil Fuels, Faculty of Geology and Geography, Sofia University \\ "St Kliment Ohridski”, 15 Tsar Osvoboditel Blvd, 1504 Sofia, Bulgaria; email: dochev@gea.uni-sofia.bg \\ ${ }^{2}$ Geological Institute, Bulgarian Academy of Sciences, Acad. G. Bonchev Str., Bl. 24, 1113 Sofia, Bulgaria; \\ e-mail: lubo@geology.bas.bg
}

(Received: 2 April 2021; accepted in revised form: 31 May 2021)

\begin{abstract}
New data on the ammonite genus Pseudokossmaticeras Spath, 1922 have been obtained from several uppermost Campanian-lower Maastrichtian strata of the Fore-Balkan Mountains (Bulgaria). A review of the earlier Bulgarian records of the genus is also presented. The following species are here described and illustrated: Pseudokossmaticeras brandti (Redtenbacher, 1873), P. galicianum (Favre, 1869), P. muratovi Michailov, 1951 and $P$. tercense (Seunes, 1892). Our newly obtained ammonite records were constrained by the inoceramid zonation that has recently been proposed for successions of the Fore-Balkan area. Hence, the Bulgarian data are of importance for correlation with other occurrences of Pseudokossmaticeras across Europe.
\end{abstract}

Dochev, D., Metodiev, L. 2021. Review of the ammonite genus Pseudokossmaticeras Spath, 1922 from the uppermost Campanian-lower Maastrichtian in Bulgaria. Geologica Balcanica 50 (2), 3-33.

Keywords: uppermost Campanian-lower Maastrichtian, ammonites, taxonomy, Bulgaria.

\section{INTRODUCTION}

Pseudokossmaticeras Spath, 1922 is a well-known ammonite genus that has often been recorded from Upper Cretaceous strata in Europe. It is best known for its distinctive and widespread species, $P$. brandti (Redtenbacher), and several other allied forms that were first described from localities in Galicia (present-day Ukraine) and France (Favre, 1869; Redtenbacher, 1873; Seunes, 1890a, b, 1892; de Grossouvre, 1894). Consequently, more progress has been made in this respect by Thiedig and Wiedmann (1976), who collected ammonites in Carinthia (Austria), as well as by Hancock and Kennedy (1993) and Kennedy and Summesberger (1987), who studied the ammonite faunas from Tercis,
Landes (France), and Ukraine. These authors, along with the papers of Kennedy and Summesberger (1991) and Summesberger and Zorn (2012), have done much to interpret the classic species of Pseudokossmaticeras. Knowledge about both the geographical and stratigraphical distribution and species composition of this genus in Europe has been greatly enriched by a number of works (e.g., Michailov, 1951; Naidin and Shimansky, 1959; Kennedy et al., 1986, 2001; Ward and Kennedy, 1993; Kennedy and Bilotte, 1995; Kennedy and Odin, 2001; Courville and Odin, 2001; Summesberger et al., 2002), and the well-dated European occurrences suggest that Pseudokossmaticeras is confined to the uppermost Campanian and mostly to the lower Maastrichtian. Stragglers outside Europe are rare 
and usually consist of a smaller number of specimens and localities: South India (Stoliczka, 1865); Madagascar (Collignon, 1938); Tunisia (Salaj and Wiedmann, 1989); South Africa (Spath, 1922; Kennedy and Klinger, 2013); Turkmenistan (Arkadiev et al., 2000); Jamaica (Donovan and Draper, 2001); and North America (Kennedy and Cobban, 1993). Thus, the European occurrences have provided the main data for our current concept of the genus.

The earliest Bulgarian record of Pseudokossmaticeras was that of Jélev (1934). From a few localities near the village of Ralyovo (Pleven District, central North Bulgaria), he described "Pachydiscus Galicianus Favre sp.", "Pachydiscus cfr. Brandti, Redt.", and "Pachydiscus Brandti var. Pegoti, Gross.”, but illustrated only the first of these taxa (Jélev, 1934, pl. 4, fig. 1). He also noted that his ammonites were obtained "from Senonian strata in association with Bostrychoceras polyplocum A. Roemer" (translated from Bulgarian by LM). At about the same time, V. Tzankov (1935, pp. 11-12, pl. 3, fig. 2) described "Kossmaticeras galizianus var. tercensis Seunes" and figured "Kossmaticeras brandti Redtenbacher". Both taxa were from a locality near Ohoden Village (Vratsa District, NW Bulgaria) from what V. Tzankov also called "Senonian”. Tz. Tzankov (1964) published ammonites accompanied by abundant inoceramid bivalves. These faunas were obtained from eight levels, indicating Maastrichtian age, in a section near the village of Kladorub (Vidin District, NW Bulgaria). Eleven ammonite species, including Pseudokossmaticeras brandti, P. galicianum and P. galicianum tercense, were described. Detailed descriptions and a number of figures of Pseudokossmaticeras were given by V. Tzankov (1982). The material of his monographic study was referred to the Maastrichtian and divided into several species, namely $P$. brandti, $P$. aturicus, $P$. galicianum and $P$. tchihatcheffi. It came from eight localities in western and central North Bulgaria, including that of the earlier paper of $\mathrm{V}$. Tzankov (1935): Novo Selo-Zavala and Yaroslavtsi (Pernik District, W Bulgaria); Kaleto, Darmantsi, Ohoden, Bukovets and Virovsko (Vratsa District, NW Bulgaria); and Ralyovo. Jolkičev (1989) noted several records of Pseudokossmaticeras brandti and used them as indicators for the Maastrichtian age of strata from the Fore-Balkan Mts but never published them. Specimens from the area between the villages of Reselets, Kunino and Dolna Beshovitsa (Vratsa and Pleven districts, NW Bulgaria), as well as from near the villages of Ralyovo and Varbinka (Varna District, East Bulgaria), were given the names $P$. brandti, $P$. galicianum and $P$. tercense.
More recently, Dochev et al. (2018) and Pavlishina et al. (2020) published a new record of $P$. brandti from the uppermost Campanian near the village of Reselets.

The current account includes our revision of the available localities and representatives of Pseudokossmaticeras from Bulgaria, but also of a new record from both previously known and new ammonite-bearing localities, Rumyantsevo (Lovech District, NW Bulgaria) and Tsonevo (Varna District, East Bulgaria), recently sampled by the authors. It should be noted that the entire material is exclusively from scattered occurrences, and therefore a superposition of these ammonites is difficult to demonstrate. The age assessments of the ammonite taxa described below are based on the stratigraphic data from both the above-listed and other related previous Bulgarian publications, and for some findings we have relied on the occurrence of accompanying inoceramid bivalves.

\section{GEOLOGICAL AND STRATIGRAPHICAL BACKGROUND}

As far back as the earliest studies of the Upper Cretaceous rocks in Bulgaria, it has been thought that, regionally, these strata represent distinct facies types. It was Zlatarski (1905) who distinguished at first the North European and South European (Mediterranean) types of Upper Cretaceous rocks in Bulgaria, and his view has remained in use to the present day. Subsequent workers (V. Tzankov et al., 1960; Vaptzarova, 1965) recognized yet another type of Upper Cretaceous rocks, called Carpathian, which is also adopted by stratigraphers studying Upper Cretaceous Series in Bulgaria. From the viewpoint of current understanding, the North European type comprises moderately thick open-shelf carbonate deposits, whereas the Mediterranean type includes expanded and lithologically diverse, sedimentary and volcano-sedimentary rocks that are the product of extensive, subduction-related back-arc igneous activity and deposition (see Dabovski et al., 2009, and references therein). The Carpathian type, in turn, corresponds to thick hemipelagic to upper slope deposits (ibid.). Apart from their overall distinct lithology and depositional settings, these types of Upper Cretaceous rocks also differ in their occurrence. The former two types are widespread and considered to be an integral part of the Moesian Platform and the marginal segments of the Balkan orogen in Bulgaria, referred to the Central BalkanFore-Balkan, East Balkan and Srednogorie zones 
(sensu Ž. Ivanov, 2017), whereas the latter type occurs narrowly, and is a part of the Kula Zone, which is assumed to represent the Carpathian orogen in Bulgaria (ibid.) (see Fig. 1a). For each of these types, there are well-developed lithostratigraphic schemes, which were summarized by Dabovski et al. (2009) and recently amplified by Sinnyovsky et al. (2012, 2013) (see Fig. 1b).

According to the above-outlined framework, sixteen localities yielded a total of 36 ammonites that are the focus of the present work. Of these, one locality represents the Carpathian type, two localities belong to the Mediterranean type, and the remaining ammonite-bearing fields are associated with the North European type of Upper Cretaceous rocks (Fig. 1; see also Table 1).

The only locality corresponding to the Carpathian type is the one near the village of Kladorub, from which Tz. Tzankov (1964) published three examples of Pseudokossmaticeras. It refers to the type section for the Kladorub Formation, which spans the upper Campanian-Ypresian and has a well-established calcareous nannofossil biostratigraphy (see Granchovski, 2019, and references therein). Following Hancock and Kennedy (1993), who subsequently revised Tz. Tzankov's (1964) Pseudokossmaticeras specimens and thought that $P$. brandti was misidentified, we agree that the record of the genus from this locality corresponds to $P$. galicianum and $P$. tercense. These taxa have been proven to be species of a firm Maastrichtian occurrence (ibid.). Furthermore, as stated by Tz. Tzankov (1964), they were found in association with other ammonite taxa, such as Pachydiscus neubergicus (von Hauer, 1858) and $P$. gollevillensis (d'Orbigny, 1850), which are also Maastrichtian in age. In addition, several coeval inoceramid specimens were listed (Tz. Tzankov, 1964, p. 146), of which one, identified as "Inoceramus impressus d'Orbigny", is a typical example of Endocostea typica Whitfield, 1880. The latter taxon is the index species for the eponymous inoceramid zone of the lower Maastrichtian (Walaszczyk et al., 2001, 2002), which has also been documented in Bulgaria (Dochev et al., 2018; Dochev and Metodiev, 2020; Pavlishina et al., 2020). Thus, P. brandti is again excluded as a record from Kladorub.

The localities of the Mediterranean type of Upper Cretaceous strata are Novo Selo-Zavala and Yaroslavtsi, both with single specimens, which were reported by V. Tzankov (1982). We confirm the previous record of $P$. brandti, recognizing one of the earlier definitions, but reinterpreting "Pseudokossmaticeras aturicus (Seunes)” as P. brandti. These occurrences are assigned, albeit conditional- ly, to the uppermost levels of the Zavala Formation. The latter unit was recently formalized by Sinnyovsky et al. (2013) and dated, based on nannofossils, as late Campanian. Hence, our interpretation confirms that the Zavala Formation embraces the upper Campanian.

The bulk of the ammonites described in this paper are from rocks of the North European type of Upper Cretaceous strata (see Fig. 1 and Table 1). In terms of lithostratigraphy, the ammonite-bearing rocks of this type belong to the Darmantsi, Darmantsi-Kunino, Yankovo, and Kunino formations. The total chronostratigraphic extent of these units has been determined as upper Campanian (pars.)lower Maastrichtian (e.g., Jolkičev, 1986, 1989; Sinnyovsky and Vangelov, 2007; Dochev, 2012; Dochev and Metodiev, 2020; Pavlishina et al., 2020). From the Darmantsi Formation, the overall record of Pseudokossmaticeras exclusively refers to $P$. brandti. Due to the lack of proper chronostratigraphic framework, previous accounts of this species from the upper Campanian, for example those from the Beglezh, Bukovets and Ralyovo localities (Jélev, 1934; V. Tzankov, 1982; Jolkičev, unpublished collection), are unreliable. Jélev (1934) claimed that his pseudokossmaticeratids co-occurred with Bostrychoceras polyplocum, which has long been known to be a late Campanian taxon (see Hancock and Kennedy, 1993), but we do not have any of his specimens for revision, and the only figured example, defined as "Pachydiscus Galicianus Favre sp.”, is herein redefined as $P$. tercense, which is a species of typically lower Maastrichtian occurrence (ibid.). With a high degree of conditionality, we refer the examples of $P$. brandti of $\mathrm{V}$. Tzankov (1982) and Jolkičev (unpublished collection) to the Darmantsi Formation, and to the upper Campanian. Thus, the only authentic late Campanian record of $P$. brandti, from the Darmantsi Formation, is that from Reselets, where two specimens were found in association with "Inoceramus" cf. wyomingensis Walaszczyk, Cobban and Harries 2001, immediately below the Campanian/Maastrichtian boundary (see Dochev et al., 2018; Pavlishina et al., 2020). The latter taxon is a characteristic inoceramid species for the uppermost Campanian, as evidenced in the U.S. Western Interior Basin and at Tercis, France (Walaszczyk et al., 2001, 2002).

Almost the same record as that of Reselets was obtained from Rumyantsevo and Tsonevo. The strata of the Darmantsi-Kunino Formation at Rumyantsevo yielded an immature individual of $P$. brandti, accompanied by Trochoceramus costaecus (Khalafova, 1969), which is also known to be restricted 


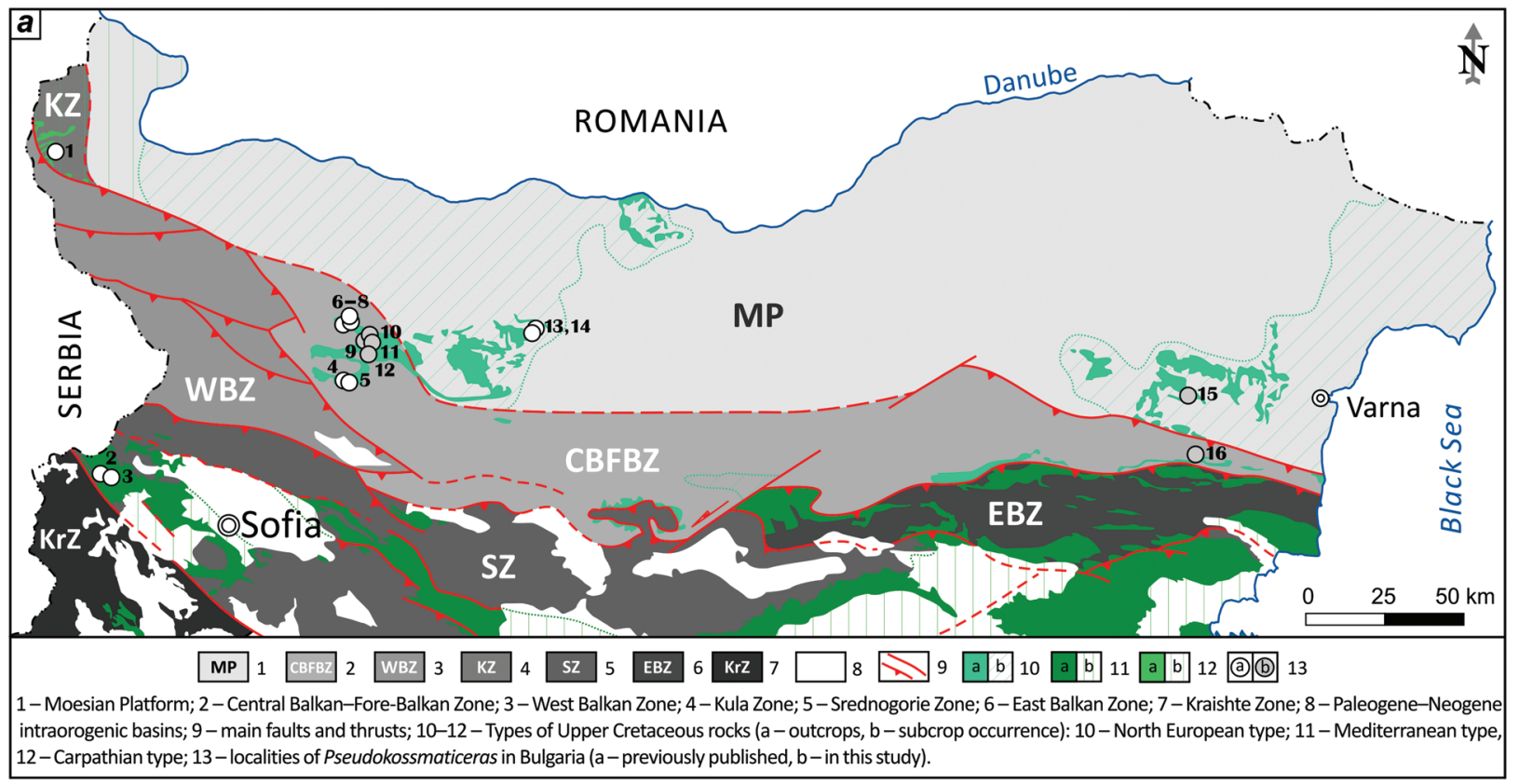

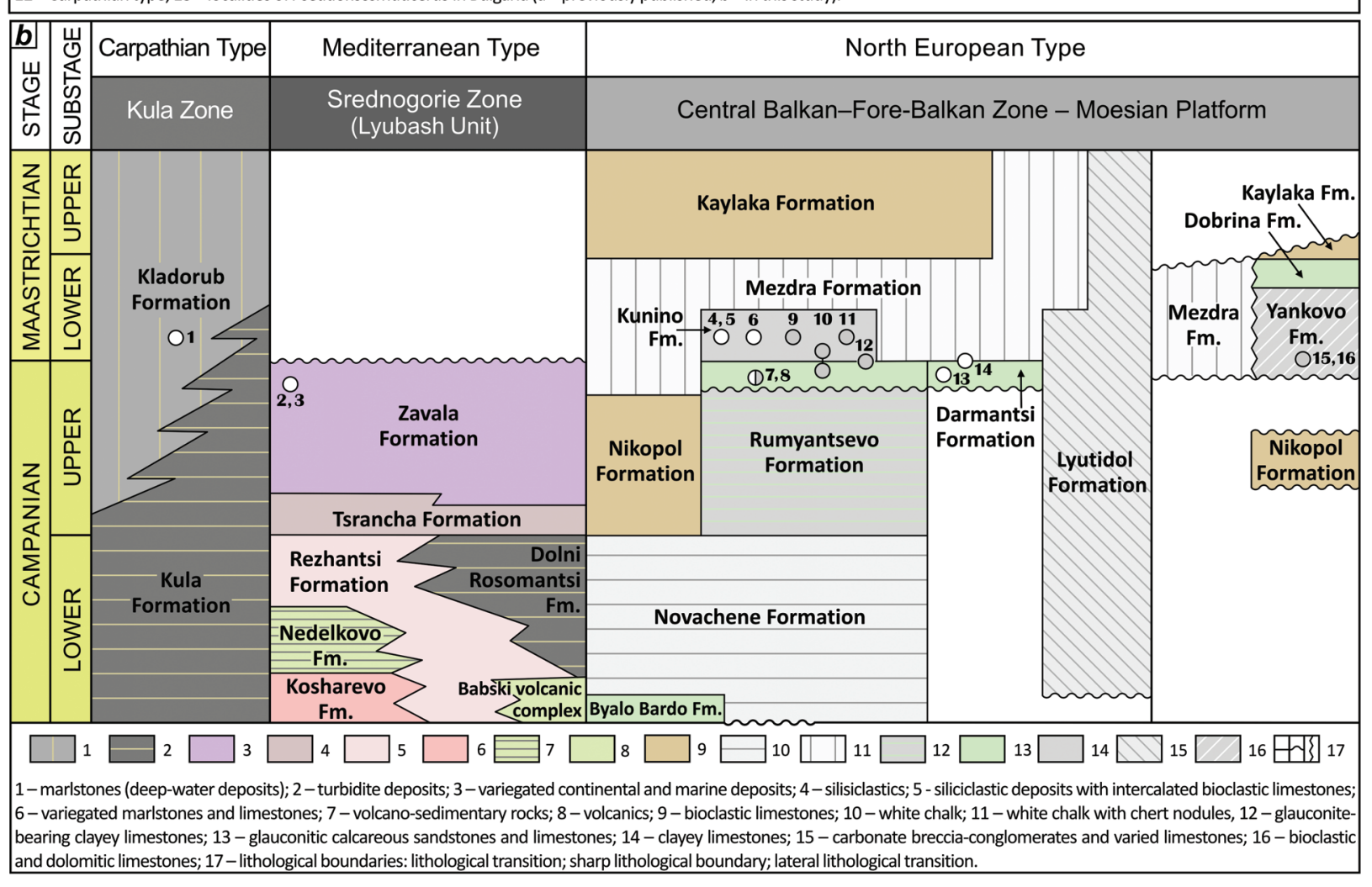

in its occurrence to the uppermost Campanian (see Walaszczyk et al., 1996, 2002). Above them were found, in superposition, the inoceramids Cataceramus subcircularis (Meek, 1876), C. barabini (Morton, 1834), and C. palliseri (Douglas, 1942), which both elsewhere and in Bulgaria have been proven to occur in the lower Maastrichtian (Walaszczyk et al., 2001, 2002; Pavlishina et al., 2020). From the Yankovo Formation at Tsonevo, we obtained single specimens of Pseudokossmaticeras cf. brandti and $P$. galicianum. Based on the age assessments for the Yankovo Formation, from nearby deposits 
Fig. 1. a) Tectonic sketch map showing the localities of Pseudokossmaticeras on the outcrop and subcrop occurrences of the Upper Cretaceous strata within the framework of the Balkan orogen in Bulgaria (after Dabovski et al., 2009, and Ž. Ivanov, 2017) (the localities are marked by a dot and a number: 1 - Kladorub; 2 - Novo Selo-Zavala; 3 - Yaroslavtsi; 4 - Kaleto; 5 - Darmantsi; 6 - Ohoden; 7 - Bukovets; 8 - Virovsko; 9 - Kunino; 10 - Reselets; 11 - Dolna Beshovitsa; 12 - Rumyantsevo; 13 - Beglezh; 14 - Ralyovo; 15 - Varbinka; 16 - Tsonevo). b) Schematic diagram of the approximate positions of ammonite localities on the simplified lithostratigraphic scheme for the Campanian-Maastrichtian rocks in Bulgaria (after Dabovski et al., 2009, and Sinnyovsky et al., 2012, 2013).

Table 1

Summary of data on the localities and sections that yielded the ammonites for this study

\begin{tabular}{|c|c|c|c|}
\hline Locality/Section & Lithostratigraphic unit & Stratigraphic age & References \\
\hline 1. Kladorub & Kladorub Fm. & lower Maastrichtian & $\begin{array}{l}\text { Tz. Tzankov (1964); Granchovski } \\
\text { (2019, and references therein) }\end{array}$ \\
\hline 2. Novo Selo-Zavala & ?Zavala Fm. & upper Campanian & $\begin{array}{l}\text { V. Tzankov (1982); } \\
\text { Sinnyovsky et al. (2013) }\end{array}$ \\
\hline 3. Yaroslavtsi & ?Zavala Fm. & upper Campanian & $\begin{array}{l}\text { V. Tzankov (1982); } \\
\text { Sinnyovsky et al. (2013) }\end{array}$ \\
\hline 4. Kaleto & ?Kunino Fm. & lower Maastrichtian & V. Tzankov (1982) \\
\hline 5. Darmantsi & Kunino Fm. & lower Maastrichtian & $\begin{array}{l}\text { V. Tzankov (1982); } \\
\text { Pavlishina et al. (2020) }\end{array}$ \\
\hline 6. Ohoden & ?Kunino Fm. & lower Maastrichtian & V. Tzankov $(1935,1982)$ \\
\hline 7. Bukovets & Darmantsi Fm. & $\begin{array}{l}\text { uppermost Campanian-- } \\
\text { lower Maastrichtian }\end{array}$ & $\begin{array}{l}\text { Jolkitschev and Vapzarova (1967); } \\
\text { V. Tzankov (1982) }\end{array}$ \\
\hline 8. Virovsko & Darmantsi Fm. & uppermost Campanian & this study \\
\hline 9. Kunino & Kunino Fm. & lower Maastrichtian & $\begin{array}{l}\text { Jolkičev (unpublished); Dochev et al. } \\
\text { (2018); Pavlishina et al. (2020); }\end{array}$ \\
\hline 10. Reselets & $\begin{array}{l}\text { Darmantsi Fm. } \\
\text { Kunino Fm. }\end{array}$ & $\begin{array}{l}\text { uppermost Campanian- } \\
\text { lower Maastrichtian }\end{array}$ & $\begin{array}{l}\text { Pavlishina et al. (2020); Jolkičev } \\
\text { (unpublished) }\end{array}$ \\
\hline 11. Dolna Beshovitsa & Kunino Fm. & lower Maastrichtian & Jolkičev (unpublished) \\
\hline 12. Rumyantsevo & Darmantsi-Kunino Fm. & uppermost Campanian & Jolkičev (1986); this study \\
\hline 13. Beglezh & ?Darmantsi Fm. & uppermost Campanian & Jélev (1934) \\
\hline 14. Ralyovo & ?Rumyantsevo Fm. & $\begin{array}{l}\text { uppermost Campanian- } \\
\text { lower Maastrichtian }\end{array}$ & $\begin{array}{l}\text { Jélev (1934); V. Tzankov (1982); } \\
\text { Jolkičev (unpublished) }\end{array}$ \\
\hline 15. Varbinka & ?Yankovo Fm. & lower Maastrichtian & Jolkičev (unpublished) \\
\hline 16. Tsonevo & Yankovo Fm. & $\begin{array}{l}\text { uppermost Campanian- } \\
\text { lower Maastrichtian }\end{array}$ & this study \\
\hline
\end{tabular}

that previously provided reliable records of nannofossils and inoceramids (Sinnyovsky and Vangelov, 2007; Dochev, 2012), we opine that our specimens relate to the upper Campanian and lower Maastrichtian levels of this unit. As another indication of the lower Maastrichtian in the Yankovo Formation, we accept a fragmentary specimen of $P$. galicianum from Varbinka (Jolkičev, unpublished collection).

The rocks of the Kunino Formation are the main source of pseudokossmaticeratids in the present work, namely $P$. muratovi, $P$. galicianum and $P$. tercense, which are related to the lower Maastrich- 
tian. The specimens available from previous workers were sufficiently supported by accompanying stratigraphic data [V. Tzankov, 1935, 1982; Tz. Tzankov, 1964 (pars.); Jolkitschev and Vapzarova, 1967; Jolkičev, unpublished], and with a few exceptions we agree with the previous identifications. In terms of the new records, it is worthy to note those from the localities of Reselets and Kunino, at which Pavlishina et al. (2020) have recently recognized the lower Maastrichtian Endocostea typica and Trochoceramus radiosus inoceramid zones in the Kunino Formation. Among the rich and continuous inoceramid assemblages, we recorded a few examples of $P$.galicianum and $P$. tercense.

\section{SYSTEMATIC PART}

The ammonites described in the present study are kept at the Museum of Palaeontology and Historical Geology at Sofia University "St Kliment Ohridski". The main part of this material was published by Tz. Tzankov (1964) and V. Tzankov (1982). Unpublished specimens, collected by Prof. Nikola Jolkičev, as well as several of our ammonites, are also included. Depending on the lithologies of the host rocks, the ammonites described herein display different degrees of preservation. All of them are composite molds, usually with well-preserved ornament. The ammonites obtained from clayey sediments are commonly fragmentary and more or less deformed, whereas those from limestones are better preserved. The latter, however, are also often distorted due to post-mortem deformations. Ammonite specimens were covered with ammonium chloride and illustrated at natural size. Standard dimensions were measured and given in millimeters and as percentages of the diameter as follows: $D$ (diameter), $W h$ (whorl height), $W b$ (whorl breadth), $U$ (umbilical diameter) (see Table 2).

Family Kossmaticeratidae Spath, 1922

Subfamily Kossmaticeratinae Spath, 1922

Genus Pseudokossmaticeras Spath, 1922
Type species. Ammonites pacificus Stoliczka, 1865, p. 160, pl. 77, fig. 9, by original designation (Spath, 1922, p. 126).

Diagnosis. Moderately evolute ammonites with rounded umbilical shoulder and whorl section, which is rather compressed than depressed. The flanks are either flat or broadly rounded. The ventrolateral shoulder and the venter are also broadly rounded. The ornamentation consists of primary ribs, rising as singles, but also in pairs and triplets, from sharp and pronounced umbilical bullae situated on the umbilical shoulder. Secondary ribs also exist, rising low, in the middle or high on the flanks. The ribs are prorsiradiate, straight or curved forwards at the ventrolateral shoulder. The bifurcate ribs cover both the inner and outer whorls, but in the adult specimens they become stronger and coarser, with intercalated short secondary ribs. The umbilical bullae are present in all stages of growth. Constrictions of varying depth can also be observed on both inner and outer whorls.

Remarks. The most extensive discussion of Pseudokossmaticeras is that of Thiedig and Wiedmann (1976). Following those authors, the species can be easily distinguished based on the type of coiling, whorl section, and the style of ornamentation in inner and outer whorls.

Occurrence. Upper Campanian-lower Maastrichtian. Europe: France, northern Spain, Poland, Austria, Italy, Ukraine (Donbass), Turkmenistan (Kopet Dagh Mountain Range), Caucasus, Crimea and Bulgaria; South India, Tunisia, Madagascar, South Africa, Jamaica, USA.

\section{Pseudokossmaticeras brandti (Redtenbacher, 1873)}

(Fig. 2a-c; Fig. 3a-d, g-h; Fig. 4h, i; Fig. 6a-c; Fig. 7e, f; Fig. 8a, b, e; Fig. $9 a-c$; Fig. 12a-d)

1873. Ammonites brandti Redtenbacher, p. 106, Pl. 24, Fig. 1.

1892. Pachydiscus aturicus Seunes, p. 17, Pl. 15 (6), Figs 2, 3.

1894. Pachydiscus brandti (Redtenbacher): de Grossouvre, p. 192, Pl. 23, Figs 1-3.

Fig. 2. Pseudokossmaticeras brandti (Redtenbacher, 1873) from the uppermost Campanian of the Western Fore-Balkan Mts. (Inv.Nr. U.S., K $\mathrm{K}_{2}$ 1794, Reselets, bed 3, Darmantsi Formation): $a$, $c$ - lateral views; $b$ - ventral view. All figures are in natural size. 


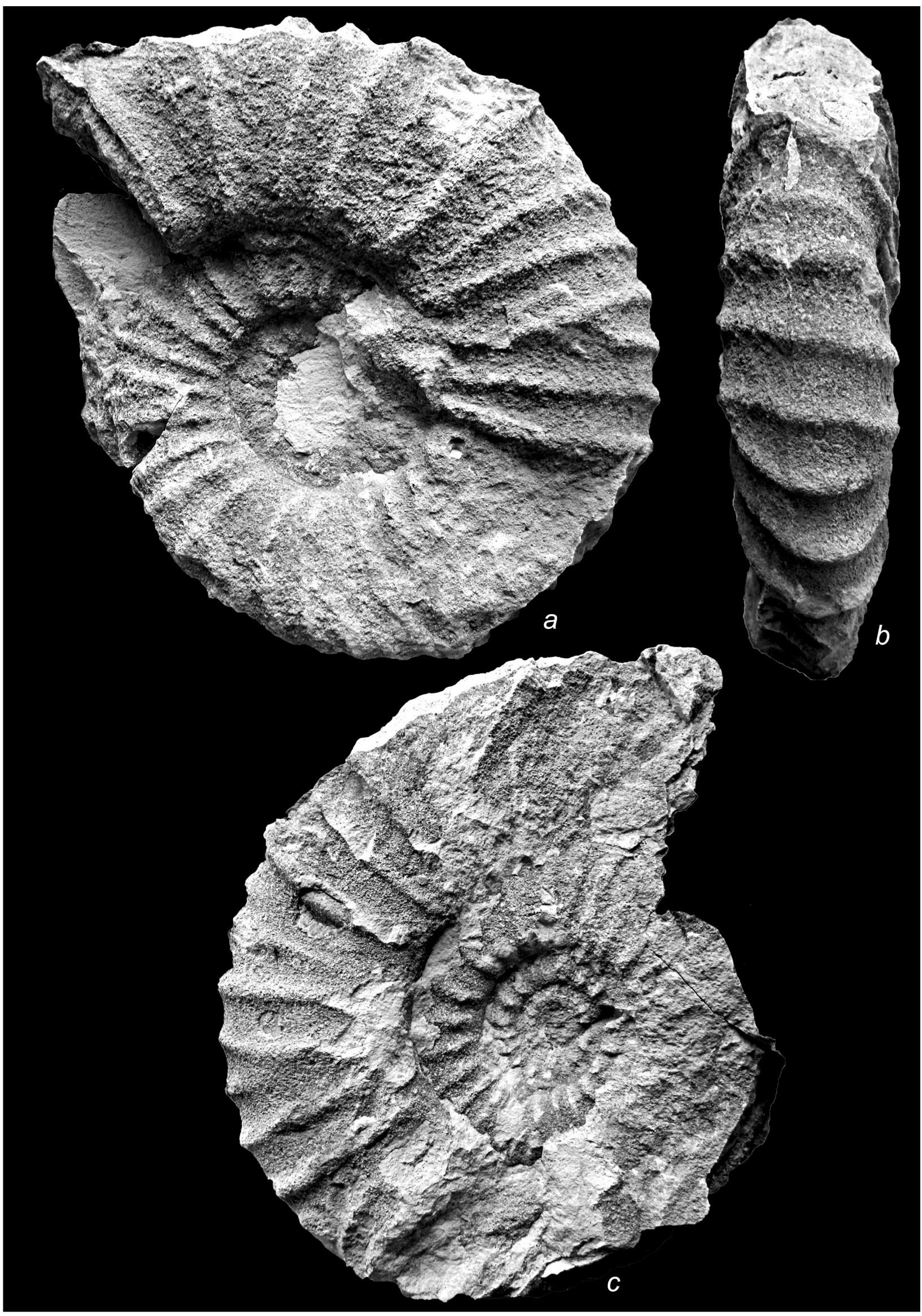


non 1894. Pachydiscus brandti var. pégoti de Grossouvre, Pl. 30, Fig. 3 [= Pseudokossmaticeras tercense (Seunes)].

1934. Pachydiscus cfr. Brandti (Redtenbacher): Jélev, p. 199.

V non 1935.Kossmaticeras brandti (Redtenbacher): V. Tzankov, Pl. 3, Fig. 2 [= Pseudokossmaticeras galicianum].

1951. Pseudokossmaticeras brandti (Redtenbacher): Michailov, p. 75, Pl. 11, Fig. 48.

1959. Pseudokossmaticeras brandti (Redtenbacher): Naidin and Shimansky, p. 190, Pl. 13, Fig. 2.

V non 1964.Pseudokossmaticeras brandti (Redtenbacher): Tz. Tzankov, p. 156, Pl. 3, Fig. 1 [= P. galicianum, Favre, 1869].

1976. Pseudokossmaticeras brandti (Redtenbacher): Thiedig and Wiedmann, p. 15, Pl. 1, Fig. 1.

V 1982. Pseudokossmaticeras brandti (Redtenbacher, 1873): V. Tzankov, p. 30, Pl. 12, Figs 1-3.

V 1982. Pseudokossmaticeras aturicus (Seunes, 1890): V. Tzankov, p. 32, Pl. 14, Fig. 1.

1989. Pseudokossmaticeras brandti (Redt): Salaj and Wiedmann, p. 303, Text-fig. 3.

1993. Pseudokossmaticeras brandti (Redtenbacher, 1873): Hancock and Kennedy, p. 155, Pl. 2, Figs 4-6; Pl. 4, Figs 1-5; Pl. 5, Figs 1-8; Pl. 6, Figs 1-9; Pl. 7, Figs 5-11.

1995. Pseudokossmaticeras brandti (Redtenbacher, 1873): Kennedy and Bilotte, p. 362, Pl. 2, Fig 1 a-c.

1997. Pseudokossmaticeras brandti (Redtenbacher, 1873): Martinez, p. 375, Fig. 1a.

1997. Pseudokossmaticeras brandti: Ward and Orr, Fig. 4-2, 4.

2001. Pseudokossmaticeras brandti (Redtenbacher, 1873): Kennedy et al., Fig. 2.

2001. Pseudokossmaticeras brandti (Redtenbacher): Courville and Odin, Pl. 7, Figs 52-54.

2001. Pseudokossmaticeras brandti (Redtenbacher): Kennedy and Odin, Pl. 1, Fig. 3.

2001. Pseudokossmaticeras brandti (Redtenbacher): Küchler et al., Pl. 4, Figs 1, 3, 5, 6.

2002. Pseudokossmaticeras brandti (Redtenbacher, 1873): Summesberger et al., p. 388, Pl. 2, Fig. 2.
2012.

Pseudokossmaticeras brandti (Redtenbacher, 1873): Summesberger and Zorn, Pl. 10, Figs 1a-c (refigured lectotype).

Lectotype. The lectotype designated by Reyment (1958, p. 34) is the specimen of Redtenbacher (1873, p. 106, pl. 24, fig. 1a, b), from the Gosau Beds of Grübach (Austria). It is housed in the collections of the Geological Survey of Austria (Inv.Nr. 1873/001/0011). The lectotype was refigured by Summesberger and Zorn (2012, pl. 10, figs 1a-c).

Material and record. Twelve specimens: Novo Selo-Zavala, probably from the Zavala Formation (Inv.-Nr. $\mathrm{Cr}_{2}$ 1138, original specimen of $\mathrm{V}$. Tzankov, 1982, pl. 14, fig. 1, 1a, refigured herein in Fig. $6 a-c$ ); Yaroslavtsi, probably from the Zavala Formation (Inv.-Nr. $\mathrm{Cr}_{2}$ 1127, original specimen of V. Tzankov, 1982, pl. 12, fig. 1, refigured herein in Fig. 8a, $b, e$ ); Bukovets, Darmantsi Formation (Inv.-Nr. $\mathrm{Cr}_{2}$ 1126, original specimen of V. Tzankov, 1982, pl. 12, fig. 3, refigured herein in Fig. 7e, f); Virovsko, Darmantsi Formation (Inv.-Nr. U.S., $\mathrm{K}_{2}$ 1806, this study); Reselets, Darmantsi Formation (Inv.-Nrs. U.S., K $\mathrm{K}_{2}$ 1794, U.S., K 1795 and U.S., $K_{2} 1800$, this study); Reselets (Kuklite area), probably from the Darmantsi Formation (Inv.-Nr. 255, unpublished specimen of Jolkičev); Rumyantsevo, Darmantsi-Kunino Formation (Inv.-Nr. U.S., $\mathrm{K}_{2}$ 1799, this study); Beglezh, probably from the Darmantsi Formation (Inv.-Nr. $\mathrm{Cr}_{2}$ 1128, original specimen of V. Tzankov, 1982, pl. 12, fig. 2, refigured herein in Fig. 4i); Ralyovo, probably from the Darmantsi Formation (Inv.-Nr. 242, unpublished specimen of Jolkičev); Tsonevo, Yankovo Formation (Inv.-Nr. U.S, $\mathrm{K}_{2}$ 1803, this study). Upper Campanian.

Measurements. See Table 2.

Description. Adult specimens reach diameters of $137 \mathrm{~mm}$ (Fig. $2 a-c$ ) and $111.3 \mathrm{~mm}$ (Fig. 7e, f) and are characterized by very evolute coiling and

Fig. 3. Latest Campanian-early Maastrichtian ammonites of the genus Pseudokossmaticeras from the Western and Eastern ForeBalkan Mts.: $a-c)$ Pseudokossmaticeras cf. brandti (Redtenbacher, 1873), Inv.-Nr. U.S., $\mathrm{K}_{2} 1803$ (Tsonevo, Yankovo Formation, uppermost Campanian); d) Pseudokossmaticeras brandti (Redtenbacher, 1873), Inv.-Nr. U.S., K 1795 (Reselets, bed 3, Darmantsi Formation, uppermost Campanian); e) Pseudokossmaticeras tercense (Seunes, 1892), Inv.-Nr. U.S., K 1802 (Reselets, bed 8, Kunino Formation, lower Maastrichtian); f) Pseudokossmaticeras galicianum (Favre, 1869), Inv.-Nr. $\mathrm{Cr}_{2} 1131$ (right view of the original specimen of V. Tzankov, 1982, pl. 13, fig. 3; Bukovets, lower Maastrichtian); g-h) Pseudokossmaticeras brandti (Redtenbacher, 1873), Inv.-Nr. U.S., K 1799 (Rumyantsevo section, base of bed 4, Darmantsi Formation, uppermost Campanian). All figures are in natural size. 


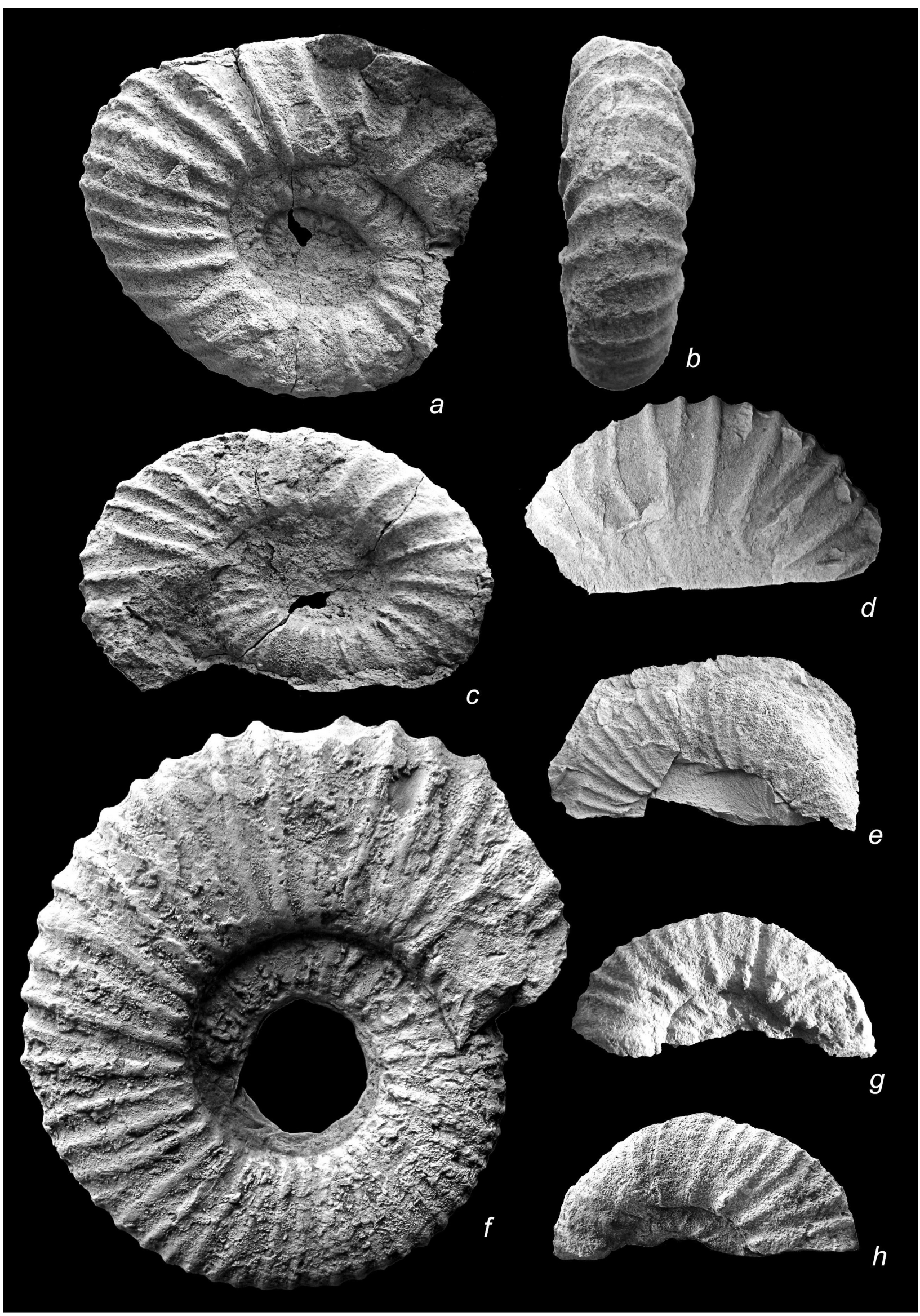


Table 2

Ammonite whorl dimensions (in $\mathrm{mm}$ ) as measured in this study

\begin{tabular}{|c|c|c|c|c|c|c|c|c|}
\hline Specimen ID & $D$ & Wh & Wh/D & $W b$ & $W b / D$ & $W b / W h$ & $\boldsymbol{U}$ & $U / D$ \\
\hline \multicolumn{9}{|c|}{ Pseudokossmaticeras brandti (Redtenbacher, 1873) } \\
\hline U.S., $\mathrm{K}_{2} 1794$ (Fig. $2 a-c$ ) & 137.0 & 40.0 & 0.29 & 27.0 & 0.20 & 0.68 & 52.0 & 0.38 \\
\hline U.S., K 21799 (Fig. 3d) & 55.0 & 17.1 & 0.31 & - & - & - & 22.0 & 0.39 \\
\hline $\mathrm{Cr}_{2} 1128$ (Fig. 4i) & 75.0 & 27.0 & 0.36 & - & - & - & 29.5 & 0.39 \\
\hline $\mathrm{Cr}_{2} 1138$ (Fig. $6 a-c$ ) & 77.0 & 24.0 & 0.31 & 26.5 & 0.34 & 1.10 & 32.0 & 0.42 \\
\hline $\mathrm{Cr}_{2} 1126$ (Fig. 7e, f) & 113.0 & 45.0 & 0.40 & 27.5 & 0.24 & 0.61 & 42.0 & 0.37 \\
\hline $\mathrm{Cr}_{2} 1127$ (Fig. 8a, $b, e$ ) & 100.3 & 37.0 & 0.37 & 36.0 & 0.36 & 0.97 & - & - \\
\hline U.S., K 21806 (Fig. $9 a-c$ ) & 101.0 & 38.0 & 0.38 & 29.0 & 0.29 & 0.76 & 41.0 & 0.41 \\
\hline No. 242 (Fig. 12d) & 72.0 & - & - & 23.0 & 0.32 & - & 29.5 & 0.41 \\
\hline No. 255 (Fig. 12a-c) & $108(81.0)$ & 50.0 & $0.46(0.62)$ & 21.0 & $0.19(0.26)$ & 0.42 & $39.0(29.8)$ & $0.36(0.37)$ \\
\hline \multicolumn{9}{|c|}{ Pseudokossmaticeras galicianum (Favre, 1869) } \\
\hline $\mathrm{Cr}_{2} 1131$ (Figs 3f, 10d) & 104.0 & 40.0 & 0.38 & 20.0 & 0.19 & 0.5 & 41.5 & 0.40 \\
\hline BAS Cr 296 (Fig. 6d) & 142.3 & 60.0 & 0.42 & - & - & - & 56.5 & 0.40 \\
\hline $\mathrm{Cr}_{2} 1136$ (Fig. 8c, d) & 122.0 & 42.0 & 0.34 & 21.2 & 0.17 & 0.5 & 42.0 & 0.34 \\
\hline $\mathrm{Cr}_{2} 1133$ (Fig. 9d, e, h) & 53.0 & 20.0 & 0.38 & 15.5 & 0.29 & 0.78 & 20.5 & 0.39 \\
\hline U.S., K 21796 (Fig. 10a, b) & - & 41.0 & - & 30.0 & - & 0.73 & 46.0 & - \\
\hline No. 258 (Fig. 11e, f) & - & 25.0 & - & 19.5 & - & 0.78 & 28.0 & - \\
\hline No. 254 (Fig. 13a, c) & $95.0(69.0)$ & 33.0 & $0.35(0.48)$ & 30.0 & $0.32(0.43)$ & 0.91 & $37.0(27.0)$ & $0.39(0.39)$ \\
\hline \multicolumn{9}{|c|}{ Pseudokossmaticeras muratovi Michailov, 1951} \\
\hline $\mathrm{Cr}_{2} 1132$ (Fig. 7d) & 60.0 & 20.0 & 0.33 & - & - & - & 28.0 & 0.47 \\
\hline \multicolumn{9}{|c|}{ Pseudokossmaticeras tercense (Seunes, 1892) } \\
\hline U.S., $\mathrm{K}_{2} 1797$ (Fig. $4 a-c$ ) & 45.0 & 14.5 & 0.32 & 10.5 & 0.23 & 0.72 & 17.5 & 0.39 \\
\hline U.S., $\mathrm{K}_{2} 1804$ (Fig. 4e, f) & $78.5(52.0)$ & 31.8 & $0.41(0.61)$ & 18.1 & $0.23(0.35)$ & 0.57 & $30.0(22.0)$ & $0.38(0.42)$ \\
\hline U.S., $\mathrm{K}_{2} 1807$ (Fig. 4j, k) & 76.0 & 28.0 & 0.37 & 21.0 & 0.28 & 0.75 & 33.5 & 0.44 \\
\hline BAS Cr 298 (Fig. $5 a-c$ ) & 93.5 & 43.5 & 0.47 & 25.0 & 0.28 & 0.57 & 37.0 & 0.40 \\
\hline U.S., $\mathrm{K}_{2} 1798$ (Fig. 7b, c) & 68.5 & 28.0 & 0.41 & 8.0 & 0.12 & 0.29 & 25.0 & 0.36 \\
\hline BAS Cr $_{2} 103$ (Figs 9f, $g ; 10 e$ ) & 71.0 & 27.1 & 0.31 & 19.5 & 0.24 & 0.72 & 30.0 & 0.42 \\
\hline
\end{tabular}

a moderately deep umbilicus. The early whorls are covered with coarse and straight single ribs, arising from prominent umbilical bullae and extending to the inner half of the flanks. The ornamentation of the outer whorls consists of 26 ribs per whorl. They are widely spaced, coarse, and straight to prorsiradiate. There are also irregular secondary ribs, usually intercalated high on the flanks. The total number of ribs is 31 per whorl. Three shallow constrictions are visible in one of the specimens (see Fig. 7e, f).

Specimen U.S., $\mathrm{K}_{2} 1803$ (Fig. $3 a-c$ ) is a deformed ammonite with a diameter of $72 \mathrm{~mm}$. It is very evolute, with compressed whorl section, and umbilical width of $35 \mathrm{~mm}$ (comprising $42 \%$ of the diameter). The ornamentation is composed of 27 ribs, including thick and prorsiradiate primary ribs, arising from

Fig. 4. Latest Campanian-early Maastrichtian ammonites of the genus Pseudokossmaticeras: $a-c)$ Pseudokossmaticeras tercense (Seunes, 1892), Inv.-Nr. U.S., K 1797 (Kunino, bed 6, Kunino Formation, lower Maastrichtian); d, g) Pseudokossmaticeras cf. tercense (Seunes, 1892), Inv.-Nr. U.S., $\mathrm{K}_{2} 1805$ (Reselets, bed 20, Kunino Formation, lower Maastrichtian); e-f) Pseudokossmaticeras galicianum (Favre, 1869), Inv.-Nr. U.S., K 1804 (Tsonevo, Yankovo Formation, lower Maastrichtian); h) Pseudokossmaticeras brandti (Redtenbacher, 1873), Inv.-Nr. U.S., K 1800 (Reselets, bed 3, Darmantsi Formation, uppermost Campanian); i) Pseudokossmaticeras brandti (Redtenbacher, 1873), Inv.-Nr. $\mathrm{Cr}_{2} 1128$ (original specimen of V. Tzankov, 1982, pl. 12, fig. 2; Beglezh, probably from the Darmantsi Formation, uppermost Campanian); j, k) Pseudokossmaticeras tercense (Seunes, 1892), Inv.-Nr. U.S., K 1807 (Reselets, bed 17, Kunino Formation, lower Maastrichtian). All figures are in natural size. 


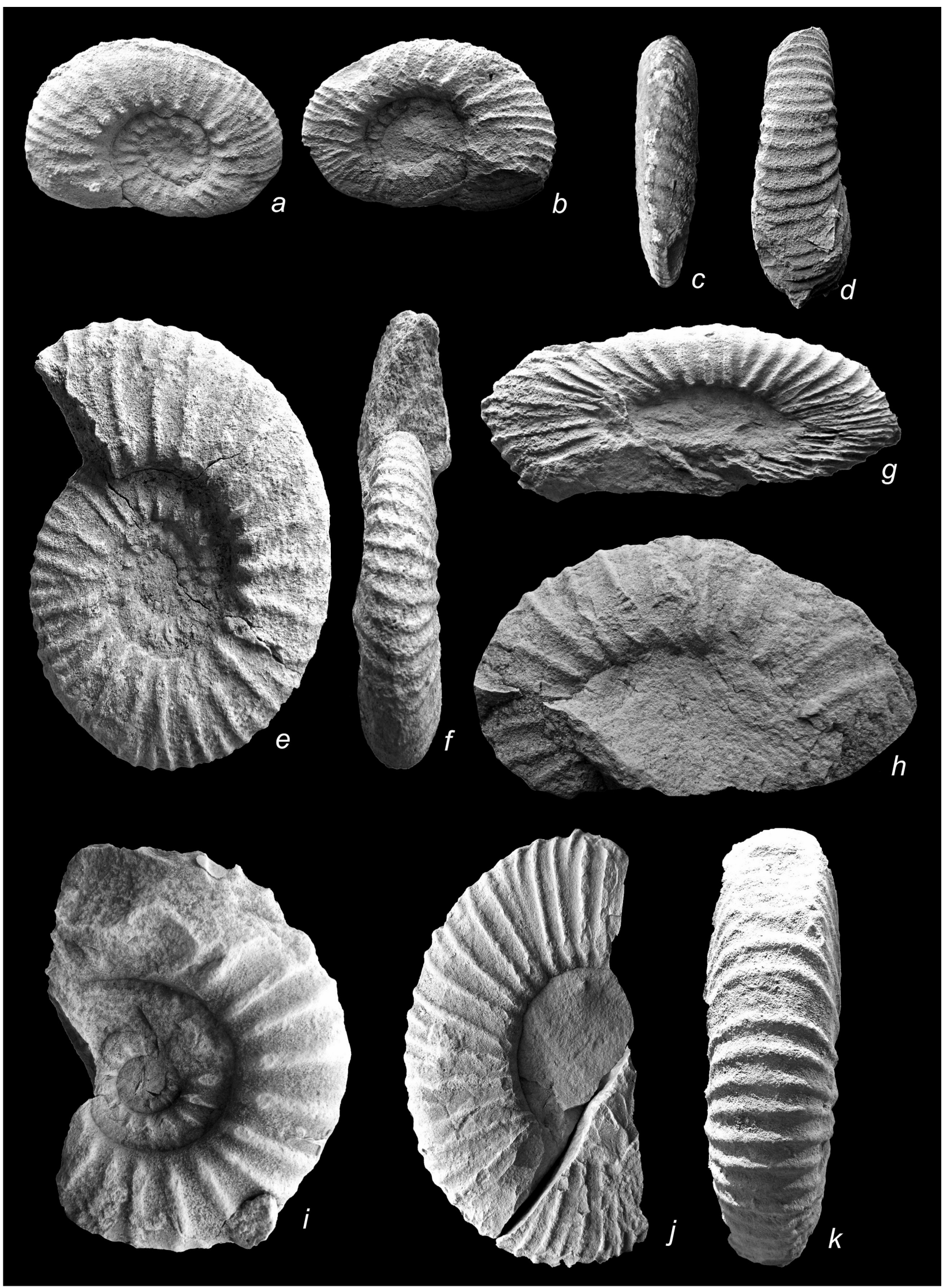


umbilical bullae, as well as intercalated secondary ribs, starting either in the middle or high on the whorl sides, and crossing the venter. The deformation of the specimen affects not only the style of coiling and whorl section, but also the ribbing style, due to which it is considered in open nomenclature.

Two specimens, with approximate diameters of $65 \mathrm{~mm}$ (Fig. 3d) and $55 \mathrm{~mm}$ (Fig. 3g, h), represent deformed whorl fragments. Specimen U.S., K 1795 (Fig. 3d) demonstrates a strong ribbing with nine prorsiradiate primary ribs and five intercalatories at the outer flank. Specimen U.S., $\mathrm{K}_{2} 1799$ (Fig. 3g, $h$ ) has nine prominent bullae at the base of the outer whorl that envelope a wide umbilicus and give rise to nine coarse primary ribs. The total number of ribs, including the secondaries, is 21. In addition, there are three constrictions that are clearly visible and framed by sharp ribs.

At larger diameters, a few more incomplete specimens (i.e., U.S., $\mathrm{K}_{2} 1800, \mathrm{D} \approx 78 \mathrm{~mm}-$ Fig. 4h; Nr. $\mathrm{Cr}_{2} 1128, \mathrm{D} \approx 75 \mathrm{~mm}$ - Fig. 4i; Nr. $\mathrm{Cr}_{2} 1127$, $\mathrm{D} \approx 100.3 \mathrm{~mm}-$ Fig. $8 a, b, e$; and U.S., $\mathrm{K}_{2} 1806$, D $\approx 100.1 \mathrm{~mm}-$ Fig. $9 a-c$ ) correspond to forms with also little overlapping and a sculpture of 7 to 14 thick primary ribs and intercalated secondaries that arise high on the flanks. Although incomplete, these specimens show that both the primary and secondary ribs become coarser and more widely spaced as the whorl height increases.

Specimen $\mathrm{Cr}_{2} 1138$ (Fig. $6 a-c$ ) is a slightly deformed evolute ammonite with almost quadrate whorl section and steep umbilical walls. The umbilicus is wide and deep, comprising $40 \%$ of the diameter. The inner whorls are sculptured with coarse and straight bullate single ribs. Twenty-five thick, straight to prorsiradiate, and widely spaced primary ribs cover the last whorl. At this growth stage, the ribs arise from prominent bullae, starting from the umbilical seam, then crossing the umbilical walls, and strengthening on the umbilical shoulder. Some of the primary ribs bifurcate high on the flanks. A total of 36 ribs are developed on the outer half of the sides and cross the venter. Six collared ribs are associated with wide and deep constrictions.

Specimen Nr. 255 (Fig. 12a, c), from the unpublished collection of Jolkičev, is well preserved but deformed to an ellipse form, with a diameter of 108 (81) $\mathrm{mm}$. The coiling is moderately evolute, with compressed whorl section. The umbilicus is shallow and wide, comprising $36 \%$ of the diameter. The ornamentation of the penultimate whorl shows 20 umbilical bullae (some of them, however, situated higher on the flanks due to deformation), which are narrow, sharp and distant. The bullae give rise to straight and rounded prorsiradiate ribs. They retain on the last preserved whorl, where 25 prorsiradiate single ribs spring from them. Occasional rib pairs are also visible. The ribs are straight on the flanks, but flexing forward on the ventrolateral shoulder. There are also 11 intercalated ribs that are developed high on the flanks. All ribs cross the venter.

Discussion. Hancock and Kennedy (1993) described and discussed this species in detail and compared it with other closely related taxa, such as Pseudokossmaticeras galicianum (Favre, 1869) and $P$. tercense (Seunes, 1892). The main difference with $P$. galicianum is that the latter possesses compressed whorl section and much finer ornamentation, which is composed of narrow ribs that arise both in singles and pairs from umbilical bullae. $P$. tercense has compressed whorls that, in earlier growth stages, are sculptured with fine, delicate, narrow ribs, whereas in the outer whorls are ornamented with bar-like ribs (Hancock and Kennedy, 1993). Pseudokossmaticeras muratovi Michailov, 1951 is more densely ribbed (more than 50 ribs per whorl) and lacks prominent umbilical bullae (Hancock and Kennedy, 1993). In addition, P. brandti has lower whorl height compared to $P$. galicianum and $P$. tercense. Hancock and Kennedy (1993) considered P. cerevicianum (Pethö, 1906) and P. aturicus (Seunes, 1892) to be junior synonyms of $P$. brandti.

The $P$. brandti specimens described and figured by V. Tzankov (1982, p. 30, pl. 12, figs 1-3), and refigured herein (Figs $4 i, 7 e, f, 8 a, b, e$ ), mainly correspond to partially preserved and deformed whorls, but there is also a well-preserved adult with a diameter of $111.3 \mathrm{~mm}$. The whorl section is generally deformed, but it seems to be depressed (Fig. 8e). The ornament of the inner whorls is composed of straight ribs, arising from umbilical bullae, whereas the outer whorls are covered by prominent, coarse, straight ribs and intercalated ribs that appear most often high on the flanks. Shallow constriction is visible on $\mathrm{Cr}_{2} 1126$ (see Fig. 7e, f). Another wellpreserved specimen, described and figured by $\mathrm{V}$. Tzankov (1982, pl. 14, fig. 1, 1a) as P. aturicus (Seunes, 1892), was also refigured herein (Fig. 6ac). It is a completely preserved form, with a diameter of $77 \mathrm{~mm}$ and ornamented with very coarse primary ribs, arising from umbilical bullae, and secondary ribs that appear on the outer part of the flanks. This style of ribbing is typical for $P$. brandti, and thus we share the opinion of Hancock and Kennedy (1993) that $P$. aturicus is synonymous with $P$. brandti.

The specimen described as $P$. brandti by Tz. Tzankov (1964, pl. 3, fig. 1 = Fig. $6 d$ herein) is 


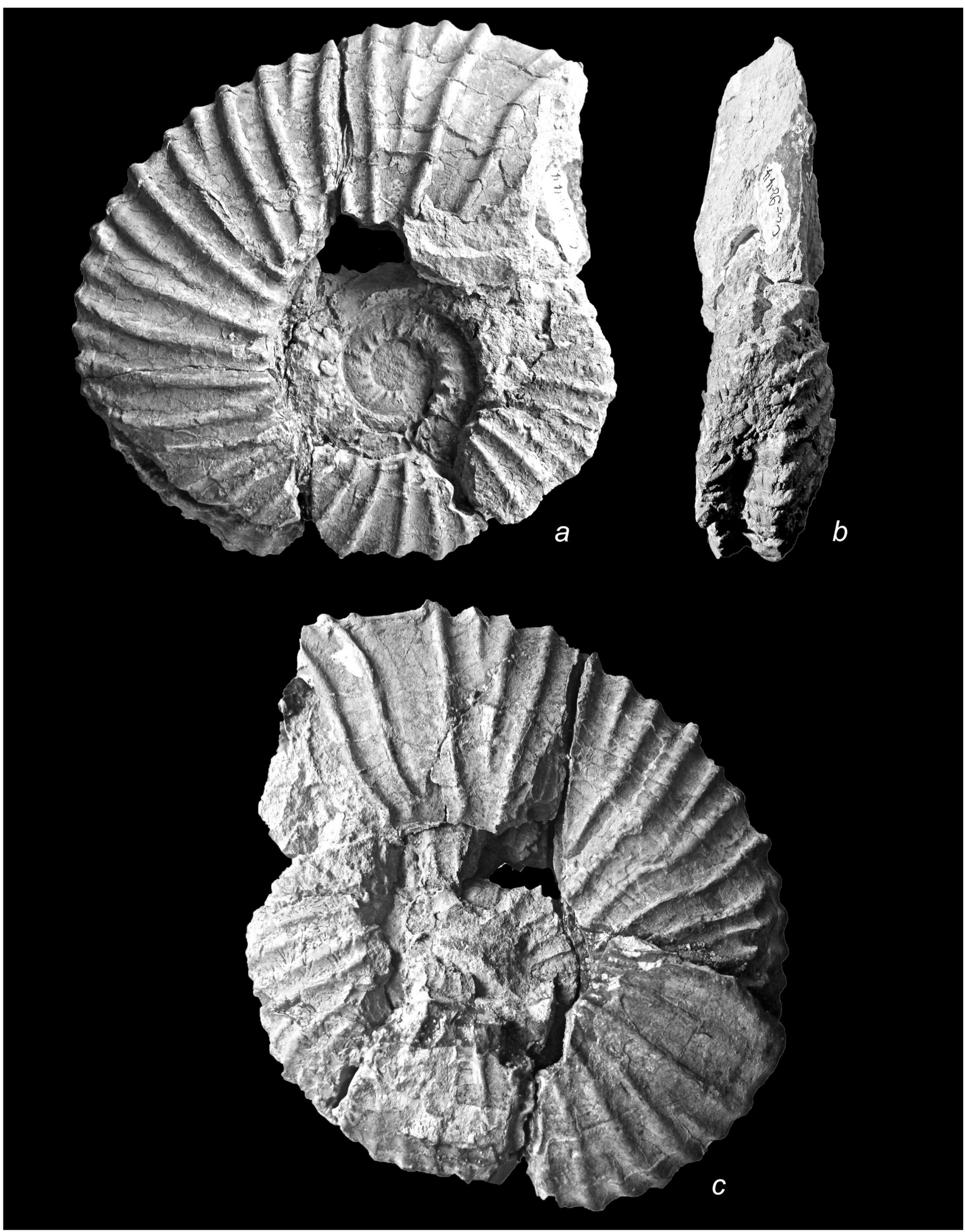

Fig. 5. Pseudokossmaticeras tercense (Seunes, 1892) from the lower Maastrichtian of the Western Fore-Balkan Mts., Inv.-Nr. BAS $\mathrm{Cr}_{2}$ 98, original specimen of Tz. Tzankov (1964, pl. 5, fig. 2), Kladorub, Kladorub Formation: $a$, $c$ - lateral views; $b$ - ventral view. All figures are in natural size. 
moderately evolute, with high whorls and shallow umbilicus. These morphological features, together with the ornamentation style (i.e., narrow ribs arising from small umbilical bullae) are typical for $P$. galicianum.

Specimen Nr. 255, from the unpublished collection of Jolkichev, closely resembles $P$. galicianum, but based on both the roughly ornamented inner whorls and the small total number of the ribs it is easily attributable to $P$. brandti.

Our newly collected specimens possess typical characteristics for $P$. brandti. They are very evolute ammonites, with coarse ornamentation that consists of primary ribs arising from prominent bullae, and secondary ribs arising usually high on the flanks (see Figs $2 a-c, 9 a-c$ ). The whorl section is compressed, due to post-mortem deformation.

Occurrence. Based on precise data from Tercis (France), Hancock and Kennedy (1993) and Kennedy et al. (2001) assigned the occurrence of $P$. brandti to the upper Campanian. The same occurrence was also documented in Austria, Spain, Crimea, Caucasus, and Tunisia. The previous Bulgarian record of $P$. brandti and $P$. aturicus $(=P$. brandti in V. Tzankov, 1982) was confined to the lower Maastrichtian, but we believe that it has upper Campanian occurrence (see above). Our new record from the Fore-Balkan localities is also confined to the uppermost Campanian.

\section{Pseudokossmaticeras galicianum (Favre, 1869)}

(Fig. 3f; Fig. 4e, f; Fig. 6d; Fig. 8c, d, f; Fig. 9d, e, $h$; $10 a-b, c, d$; Fig. 11a-f; Fig. 13a-g)

1869. Ammonites galicianus Favre, p. 16, Pl. 3, Figs 5, 6. non 1872 Ammonites galicianus Favre: Schlüter, p. 63, Pl. 19, Figs 3-5; Pl. 20, Fig. 9.

non 1890b. Pachydiscus aff. galicianum Favre: Seunes, p. 283, Pl. 9, Fig. 5.

1894. Pachydiscus galicianus Favre: de Grossouvre, p. 177.

1898. Pachydiscus negri Mariani: p. 54, Pl. 8 (1), Fig. 3.
1898. Pachydiscus galicianus Favre sp., Mariani, p. 55, Pl 8 (1), Fig. 4.

?1927. Kossmaticeras tchihatcheffi Böhm, p. 121, Pl. 13, Fig. 1.

non 1934. Pachydiscus Galicianus Favre sp.: Jélev, p. 198, Pl. 4, Fig. 1 [= Pseudokossmaticeras tercense].

V 1935. Kossmaticeras brandti Redtenbacher: Tzankov, p. 11, Pl. 3, Fig. 2.

1951. Pseudokossmaticeras cf. galicianum Favre: Michailov, p. 78, Pl. 7, Fig. 38; Text-fig. 26.

non 1959. Pseudokossmaticeras galicianum (Favre): Naidin and Shimansky, p. 189, Pl. 13, Fig. 1.

V 1964. Pseudokossmaticeras brandti (Redtenbacher, 1873): Tz. Tzankov, p. 156, Pl. 3, Fig. 1.

V non 1964.Pseudokossmaticeras galicianum (Favre, 1869): Tz. Tzankov, p. 157, Pl. 4, Fig.1; Pl. 5, Fig. 2 [= Pseudokossmaticeras tercense].

non 1974. Pseudokossmaticeras galicianum (Favre): Naidin, p. 179, Pl. 65, Fig. 4.

1976. Pseudokossmaticeras galicianum (Favre): Thiedig and Wiedmann, p. 17, Pl. 2. Figs 1, 3.

1980. Pseudokossmaticeras galicianum (Favre, 1869): Błaszkiewicz, p. 41, Pl. 56, Figs 1, 3.

V 1982. Pseudokossmaticeras galicianum (Favre, 1869): V. Tzankov, p. 31, Pl. 13, Figs 1, 3.

V non 1982.Pseudokossmaticeras galicianum (Favre, 1869): V. Tzankov, p. 31, Pl. 13, Fig. 2 (= Pseudokossmaticeras muratovi Michailov, 1951).

V 1982. Pseudokossmaticeras tchihatcheffi (Böhm, 1927): V. Tzankov, p. 32, Pl. 13, Figs 4, 5.

1987. Pseudokossmaticeras galicianum (Favre, 1869): Kennedy and Summesberger, p. 28, Pl. 2, Fig. 6 (refigured lectotype); Pl. 3, Figs 7-9 (refigured paralectotype).

1991. Pseudokossmaticeras galicianum (Favre, 1869): Kennedy and Summesberger, Pl. 1, Figs 1-6 (Figs $1-2$ = refigured paralectotype; Figs 3-6 = refigured lectotype).

2001. Pseudokossmaticeras galicianum (Favre, 1869): Kühler et al., Pl. 4, Figs 4, 7.

? 2001. Pseudokossmaticeras galicianum (Favre, 1869): Kennedy and Odin, Pl. 1, Fig. 2.

2012. Pseudokossmaticeras galicianum (Favre, 1869): Summesberger and Zorn, Pl. 6, Figs 1a-d (refigured lectotype); Figs 2a-c (refigured paralectotype).

Fig. 6. Latest Campanian-early Maastrichtian ammonites of the genus Pseudokossmaticeras: a-c) Pseudokossmaticeras brandti (Redtenbacher, 1873), Inv.-Nr. Cr 2 1138, original specimen of V. Tzankov (1982, pl. 14, fig. 1, 1a), Novo Selo-Zavala (Zavala Formation, uppermost Campanian); d) Pseudokossmaticeras galicianum (Favre, 1869), Inv.-Nr. BAS $\mathrm{Cr}_{2}$ 96, original specimen of Tz. Tzankov (1964, pl. 3, fig. 1), Kladorub (Kladorub Formation, lower Maastrichtian). All figures are in natural size. 


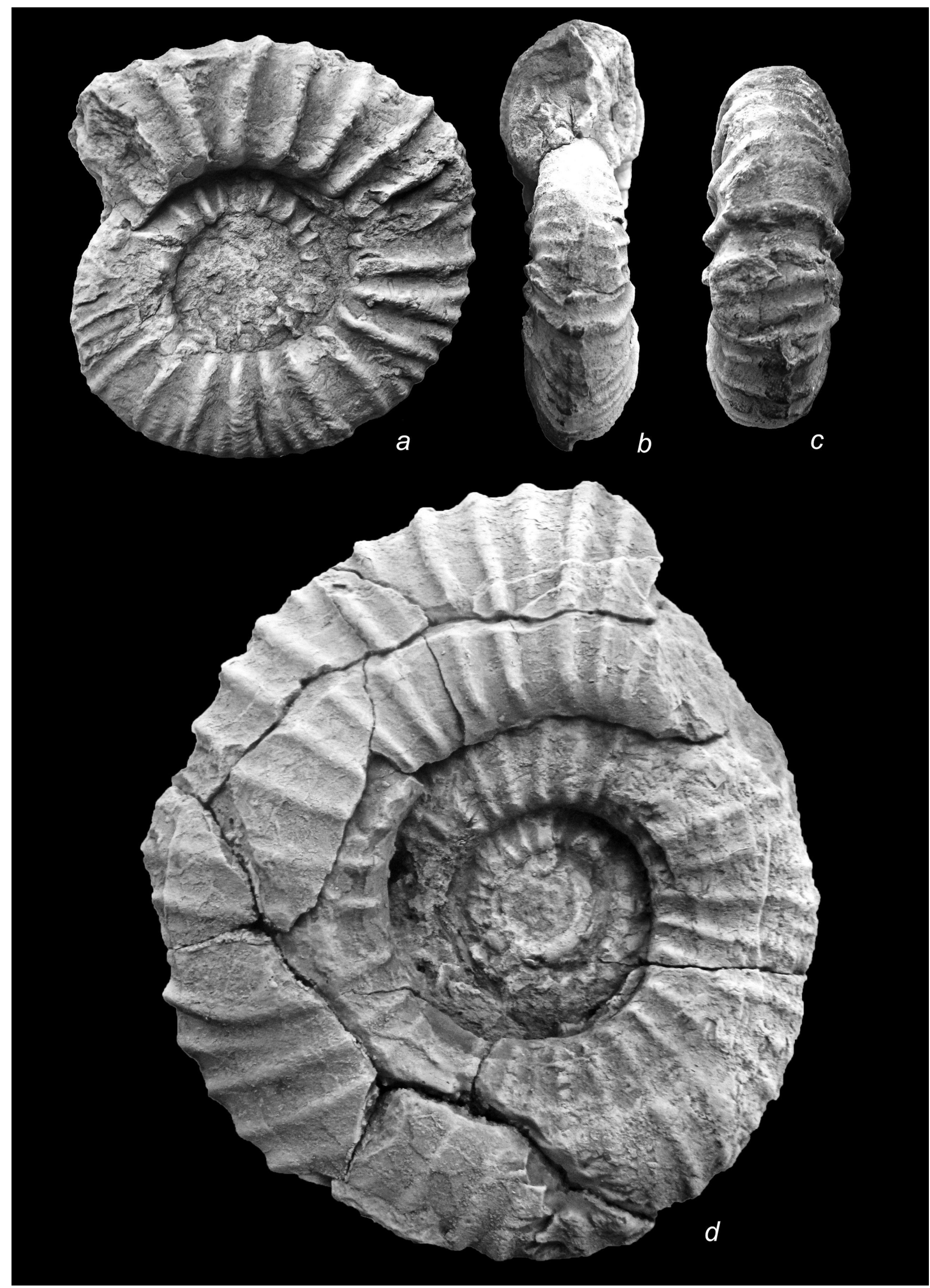


Lectotype. The lectotype is a specimen of Favre (1869, pl. 3, fig. 5; GBA 1869/006/0010/01), designated by Thiedig and Wiedmann (1976, p. 17), from the lower Maastrichtian at Nagoryany (Ukraine). It was refigured by Kennedy and Summesberger (1987, pl. 2, fig. 6; 1991, pl. 1, figs 3-6) and Summesberger and Zorn (2012, pl. 6, fig. 1). A paralectotype (Favre, 1986, pl. 3, fig. 6; GBA $1869 / 006 / 0010 / 02)$, from the same locality and level as the lectotype, is also known. It was refigured by Kennedy and Summesberger (1987, pl. 3, figs 7-9; 1991, pl. 1, figs 1, 2) and Summesberger and Zorn (2012, pl. 6, figs 2 a-c). Both original specimens are housed in the collections of the Geological Survey of Austria.

Material and record. Fourteen specimens: Darmantsi, Kunino Formation (Inv.-Nr. $\mathrm{Cr}_{2}$ 1133, original specimen of V. Tzankov, 1982, pl. 13, figs 1, 1a, refigured herein in Fig. 9d, e, h); Ohoden, probably from the Kunino Formation (Inv.-Nrs. $\mathrm{Cr}_{2} 1136$ and $\mathrm{Cr}_{2}$ 1137, original specimens of V. Tzankov, 1982, pl. 13, fig. 5, refigured herein in Fig. 8c, $d$, f); Bukovets, Kunino Formation (Inv.-Nr. BAS $\mathrm{Cr}_{2}$ 96, original specimen of Tz. Tzankov, 1964, pl. 3, fig. 1, refigured herein in Fig. 6d; Inv.-Nr. $\mathrm{Cr}_{2}$ 1131, original specimen of V. Tzankov, 1982, pl. 13, fig. 3, refigured herein in Fig. $3 f$ (right view); Inv.-Nr. U.S., $K_{2}$ 1801; Kunino, Kunino Formation [Inv.Nr. U.S., $K_{2}$ 1796, this study; Inv. Nrs. 254, 256 (two specimens) and 258, unpublished specimens of Jolkičev]; Dolna Beshovitsa, Kunino Formation (Inv.-Nr. 3940, unpublished specimen of Jolkičev); Varbinka, probably from the Yankovo Formation (Inv.-Nr. 5047, unpublished specimen of Jolkičev); Tsonevo, Yankovo Formation (Inv.-Nr. U.S., $\mathrm{K}_{2}$ 1804, this study). Lower Maastrichtian.

Measurements. See Table 2.

Description. The ammonites published by Tz. Tzankov (1964, pl. 3, fig. 1, refigured here in Fig. 6d) and V. Tzankov (1982, pl. 13, fig. 3; Figs 3f,
$10 d$ in this study) are well-preserved adult forms having diameters of $142.3 \mathrm{~mm}$ and $104 \mathrm{~mm}$, respectively. These are moderately evolute, with wide umbilicus and compressed whorl sections. The compression of the whorls is a result of compactional flattening. The umbilical walls and shoulders are rounded. Whorl sides are flat to slightly convex. In specimen $\mathrm{Cr}_{2} 1131$ (Figs 3f, 10d), 32 rounded and distant primary prorsiradiate ribs arise from narrow and sharp bullae situated on the umbilical shoulder. There are also nine secondary ribs developed high on the flanks. In the last half of the phragmocone, the ribs become more prominent and higher. Several wider and deeper rib interspaces appear to be shallow constrictions.

Specimen U.S., $\mathrm{K}_{2} 1804$ (Fig. 4e, $f$ ) is deformed to an elliptical shape, with a diameter of 78.5 (52) mm. The whorl section is very compressed $(\mathrm{Wb} / \mathrm{Wh}=$ $0.56)$ due to taphonomic flattening. The umbilicus is moderately wide (38\% of the diameter). The whorl sides are flat to slightly convex, convergent towards a rounded venter. Although the inner whorls are not well visible, the ornament at these growth stages appears to be represented by narrow and sharp, prorsiradiate, bullate ribs. On the last preserved whorl, 23 umbilical bullae arise from the umbilical seam. Bullae strengthen on the umbilical wall and are most pronounced on the umbilical shoulder. They give rise to wide and straight, flat to round-topped prorsiradiate primary ribs. From the beginning to the middle of the last whorl, some of the primary ribs may bifurcate either from the umbilical shoulder or in mid-flanks, giving rise to wide and roundtopped secondary ribs. One or two intercalated ribs are also visible. The interspaces between the primary ribs become wider on the body chamber, and both the primary and secondary ribs become coarser and narrower.

The specimens of V. Tzankov (1982, pl. 13, figs $4,5)$ are fragments of moderately evolute whorls;

Fig. 7. Latest Campanian-early Maastrichtian ammonites of the genus Pseudokossmaticeras from the Western Fore-Balkan Mts.: a) Pseudokossmaticeras tercense (Seunes, 1890), Inv.-Nr. BAS $\mathrm{Cr}_{2}$ 97, original specimen of Tz. Tzankov (1964, pl. 4, fig. 1), Kladorub, Kladorub Formation, lower Maastrichtian; $b-c)$ Pseudokossmaticeras tercense (Seunes, 1892), Inv.-Nr. U.S., K 21798 (Kunino, bed 9, Kunino Formation, lower Maastrichtian); d) Pseudokossmaticeras muratovi Michailov, 1951 (Inv.-Nr. Cr 21132 , original specimen of V. Tzankov (1982, pl. 13, fig. 2), Kaleto, probably from the Kunino Formation, lower Maastrichtian; $e-f$ ) Pseudokossmaticeras brandti (Redtenbacher, 1873), Inv.-Nr. $\mathrm{Cr}_{2}$ 1126, original specimen of V. Tzankov (1982, pl. 12, fig. 3), Bukovets, Darmantsi Formation, uppermost Campanian. All figures are in natural size. 


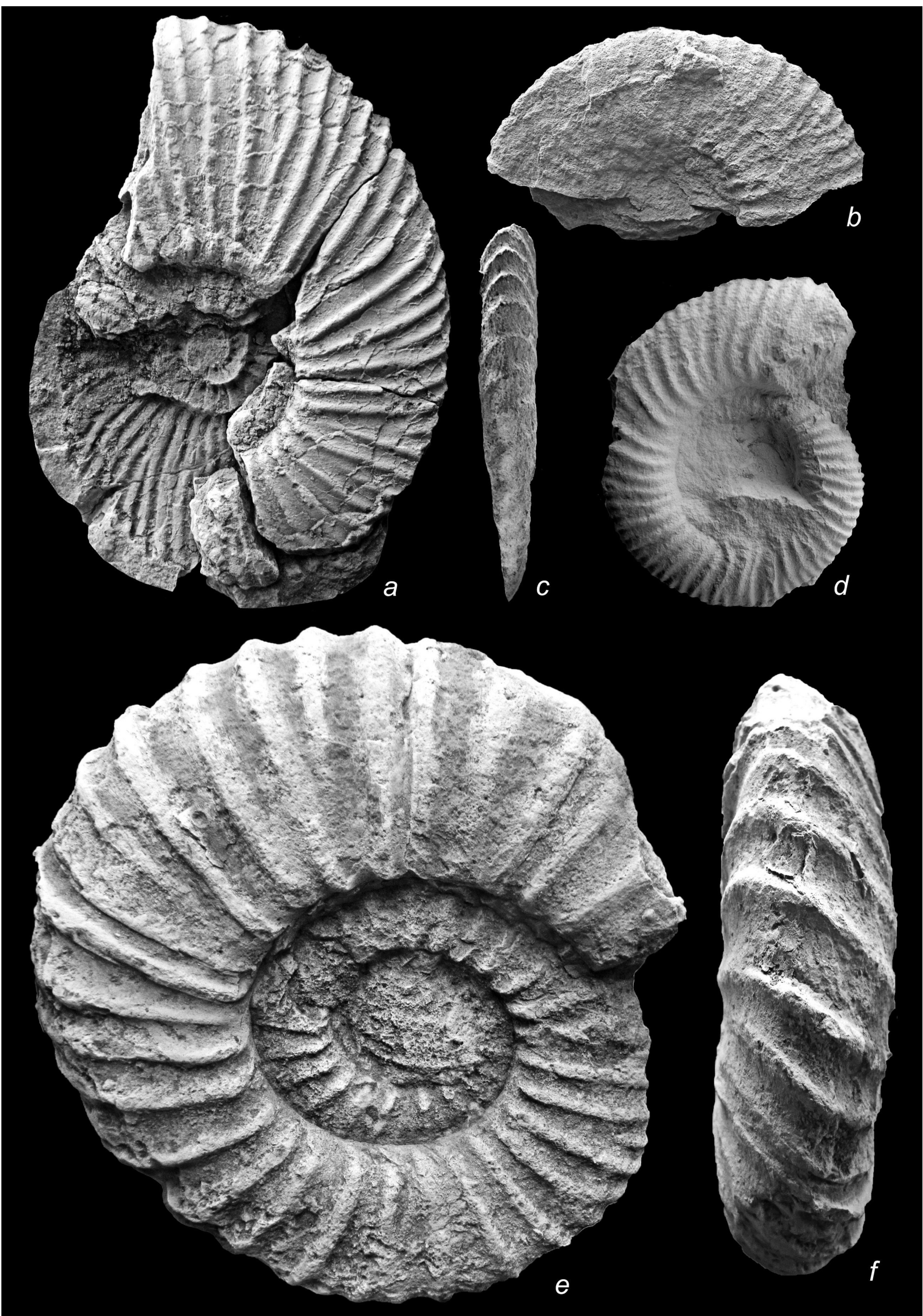


the umbilical wall is flat and subvertical, with moderately rounded shoulder (see Fig. $8 c, d$, $f$ ). The inner whorls are ornamented with straight primary ribs starting from small umbilical bullae. Long secondary ribs are seen to be intercalated between the primaries. The sculpture of the last half whorls consists of 15 prorsiradiate primary ribs arising from sharp umbilical bullae. Some of the primaries appear to bifurcate above the mid-flanks, and eight intercalated ribs are present. The ribs are straight at $2 / 3$ of the flanks, then bend forward on the ventrolateral shoulder, and cross the venter.

The juvenile specimen $(D=53 \mathrm{~mm})$ in Fig. $9 d$, $e, h$ is the original of V. Tzankov (1982, pl. 13, figs $1,1 \mathrm{a})$ and is moderately evolute, with compressed whorls. The umbilicus is wide (38.6\% of the diameter), with almost flat and subvertical umbilical wall and narrowly rounded umbilical shoulder. The inner half of the flanks is rounded, whereas the outer half is convergent towards a broadly rounded venter. Small bullae (22 in total) arise from the umbilical seam and strengthen upon the umbilical wall, becoming sharp on the umbilical shoulder (see Fig. 9h) Straight and prorsiradiate, mainly single, ribs start from the umbilical bullae. Although irregularly, secondary ribs are also present in the outer parts of the flanks. The latter are intercalatory, but some of them are obliquely connected to the primaries and appear to bifurcate. The total number of ribs is 30. All ribs cross the venter. On the inner half of the flanks, the constrictions are straight, while on the outer half they are slightly bent forwards.

Specimen Nr. 258 (Fig. 11e, f), from the unpublished collection of Jolkičev, is a partially preserved ammonite with a compressed whorl section. The umbilicus is wide, with rounded wall and shoulder. The preserved part of the inner whorls is sculptured with closely spaced, narrow and sharp umbilical bullae, each giving rise to sharp prorsiradiate ribs. The outermost preserved whorl is ornamented with 14 primary ribs arising as singles (rarely in pairs) from small umbilical bullae. Several intercalated ribs in the outer part of the flanks are also visible.

Specimen Nr. 254 (Fig. 13a-c), from the unpublished collection of Jolkičev, is a slightly deformed ammonite with a diameter of 95 (69) $\mathrm{mm}$ and well-preserved ornament. It is moderately evolute; flanks are slightly convex, and both the ventrolateral shoulder and venter are broadly rounded. The whorl section is slightly compressed $(\mathrm{Wb} / \mathrm{Wh}$ $=0.9$ ). The umbilicus is deep and wide, comprising $38 \%$ of the diameter. The umbilical wall is subvertical, with rounded umbilical shoulder. On the penultimate whorl, there are 21 bullae that are extended from the umbilical seam to the umbilical shoulder. The bullae are narrow and sharp, with wide interspaces. At the outermost part of the penultimate whorl, bullae give rise to narrow and straight prorsiradiate ribs. The umbilical bullae continue on the last whorl, where they are arranged on the umbilical shoulder and give rise to 24 straight, rounded prorsiradiate primary ribs. One, rarely two, rounded ribs are intercalated between the primaries. Most of the intercalated ribs (19 in total) arise high on the flanks, but some of them appear to be linked to the primaries low on or in the middle of the flanks. All ribs cross the venter. There are also three shallow, barely visible constrictions on the last whorl.

Discussion. The moderately evolute coiling, the compressed whorl section, as well as the style of ornamentation that consists of equally pronounced primary and secondary ribs are the main characteristics of $P$. galicianum. Pseudokossmaticeras tercense (Seunes, 1892) is very similar to $P$. galicianum but differs in having higher whorls and finer ornament, in which the secondary ribs arise lower on the flanks and markedly distinguished in relief from the primaries (Kennedy and Summesberger, 1987).

Kennedy and Summesberger (1987) revised and discussed P. galicianum and concluded that Pseudokossmaticeras tchihatcheffi (Böhm, 1927) is a

Fig. 8. Latest Campanian-early Maastrichtian ammonites of the genus Pseudokossmaticeras from the Western Fore-Balkan Mts.: $a, b, e)$ Pseudokossmaticeras brandti (Redtenbacher, 1873), Inv.-Nr. $\mathrm{Cr}_{2}$ 1127, original specimen of V. Tzankov (1982, pl. 12, fig. 1), Yaroslavtsi, probably from the Zavala Formation, uppermost Campanian); c, d) Pseudokossmaticeras galicianum (Favre, 1869), Inv.-Nr. $\mathrm{Cr}_{2}$ 1136, original specimen of V. Tzankov (1982, pl. 13, fig. 5), Ohoden, probably from the Kunino Formation, lower Maastrichtian; f) Pseudokossmaticeras galicianum (Favre, 1869), Inv.-Nr. Cr 2 1137, original specimen of V. Tzankov (1982, pl. 13, fig. 4) from the same locality and level as $c, d$. All figures are in natural size. 


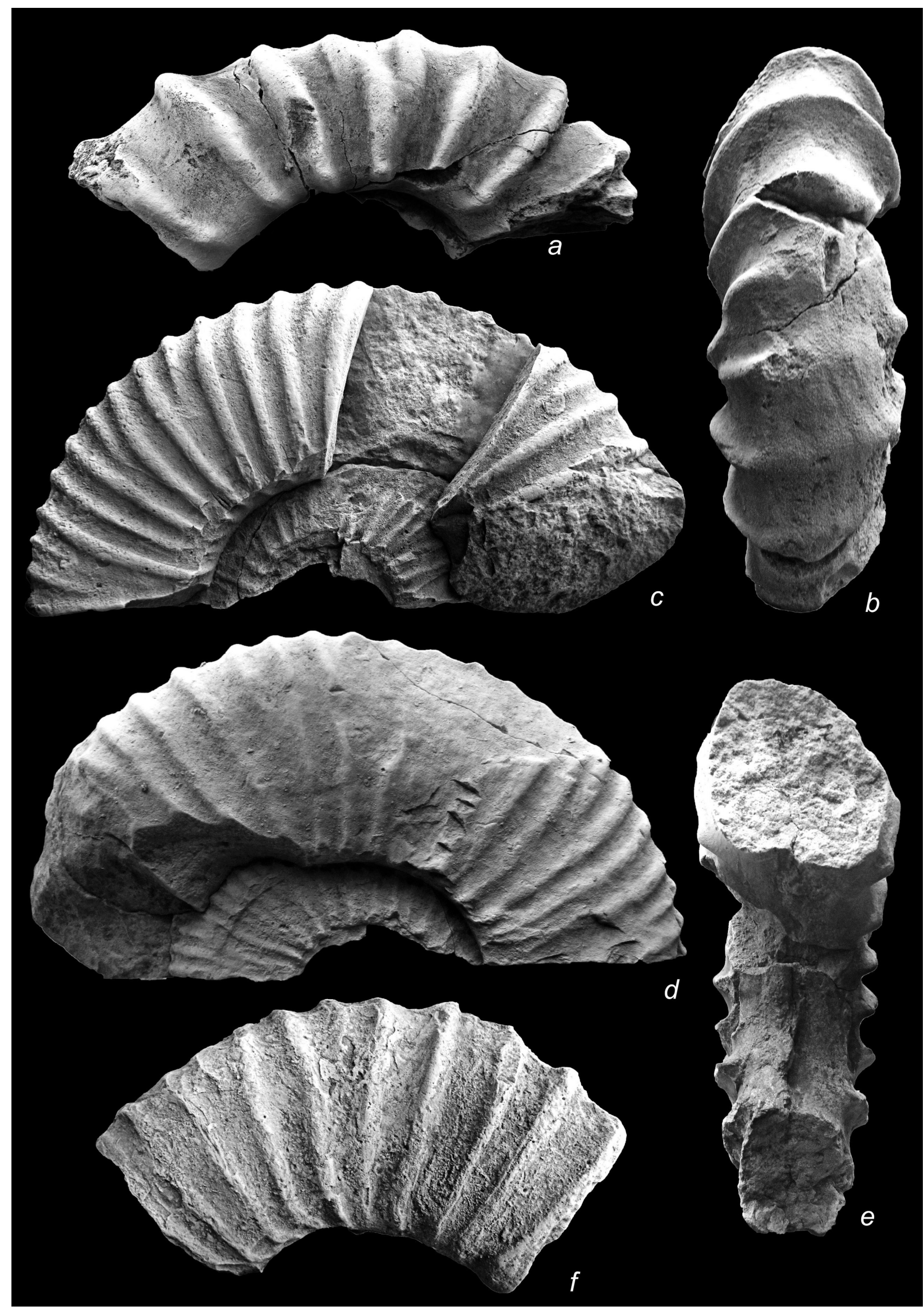


junior synonym of it. In two later works, a description was made, and the lectotype and paralectotype of $P$. galicianum were refigured (see Kennedy and Summesberger, 1991; Summesberger and Zorn, 2012). Following the opinion of these authors, we interpret the examples previously defined as $P$. tchihatcheffi by V. Tzankov (1982, pl. 13, figs 4, 5) as belonging to $P$. galicianum. Other definitions from the older Bulgarian literature that we believe to fit in P. galicianum are those of V. Tzankov (1982, pl. 13, fig. 3) and Tz. Tzankov (1964, pl. 3, fig. 1). The former corresponds to a specimen that shows enough morphological attributes to be interpreted as P. galicianum (see Fig. 3f, right view; Fig. 10d, left view), but also shows similarities with $P$. tercense (Seunes, 1892). However, at a larger diameter, $P$. tercense usually has a bigger whorl height, and in addition the secondary ribbing is developed lower on the flanks. Tz. Tzankov (ibid.) defined his specimen as $P$. brandti, but it is moderately evolute and has a denser ornamentation than the typical examples of this species, and therefore we interpret it as P. galicianum.

Specimen U.S., $\mathrm{K}_{2} 1801$ (Fig. 10c) is a poorly preserved ammonite with an approximate diameter of $110 \mathrm{~mm}$. In the inner whorls, primary and secondary ribs are visible; the ribs are straight to the mid-flanks and flexing forwards in the ventrolateral area; secondary ribs are also present. The sculpture of the last preserved whorl consists of relatively closely spaced prorsiradiate ribs, which have the same projection as in the inner whorls. Rare secondary ribs, rising high on the flanks, are also visible. This specimen has both coiling and ornamentation styles that are typical for $P$. galicianum, but since it is poorly preserved we define it conditionally.

It should be noted that specimen Nr. 254 (Fig. 13a-c), from the unpublished collection of Jolkičev, shows some morphological attributes that are rather characteristic for $P$. tercense. For instance, the narrow and closely spaced primary ribs, as well as the closely spaced secondary ribs that arise occasionally low on the flanks, are not typical for $P$. galicianum. However, this ammonite has roughly sculptured inner whorls and almost quadrate whorl section, which are both not observed in P. tercense.

Occurrence. The only record of $P$. galicianum from the upper Campanian was that of Błaszkiewicz (1980) from Poland. This species is widely recorded in the lower Maastrichtian of Ukraine, Crimea, Austria, France, and Spain. The record presented herein is also from the lower Maastrichtian.

\section{Pseudokossmaticeras muratovi Michailov, 1951 (Fig. 7d)}

1951. Pseudokossmaticeras muratovi Michailov, p. 77, Pl. 13, Fig. 52.

V 1982. Pseudokossmaticeras galicianum Seunes: V. Tzankov, Pl. 13, Fig. 2.

1984. Pseudokossmaticeras muratovi Michailov: Yamnichenko and Astachova, p. 86, Pl. 53, Fig. 1.

Holotype. The holotype is specimen 3501/67 of Michailov (1951, p. 77, Pl. 13, Fig. 52) from the lower Maastrichtian of Bakhchisaray region, Crimea. It is housed at the Museum of the Institute for Geological Sciences (Ukraine).

Material and record. One specimen: Kaleto, probably from the Kunino Formation (Inv.-Nr. $\mathrm{Cr}_{2}$ 1132, original specimen of V. Tzankov, 1982, pl. 13, fig. 2, refigured herein in Fig. 7d). Lower Maastrichtian. Measurements. See Table 2.

Description. The only specimen we have is a cast of an imprint (see Fig. 7d). It is a small and moderately evolute ammonite, with rounded umbilical area. Thirty-four slightly bullate primary ribs arise from the umbilical wall. The ribs are initially concave, and then bend forward on the flanks. Ribs bifurcate mid- to high on the flanks. A total of more than 60 ribs cross the venter. Three shallow constrictions,

Fig. 9. Latest Campanian-lower Maastrichtian ammonites of the genus Pseudokossmaticeras from the Western Fore-Balkan Mts.: a-c) Pseudokossmaticeras brandti (Redtenbacher, 1873), Inv.-Nr. U.S., K 1806 (Virovsko, Darmantsi Formation, uppermost Campanian); $d, e, h)$ Pseudokossmaticeras galicianum (Favre, 1869), Inv.-Nr. Cr 21133 (original specimen of V. Tzankov, 1982, pl. 13, fig. 1, 1a, Darmantsi, Kunino Formation, lower Maastrichtian); f, g) Pseudokossmaticeras tercense (Seunes, 1890), Inv.-Nr. BAS $\mathrm{Cr}_{2} 103$ (original specimen of Tz. Tzankov, 1964, pl. 6, fig. 1), right view; Kladorub, Kladorub Formation, lower Maastrichtian). All figures are in natural size. 


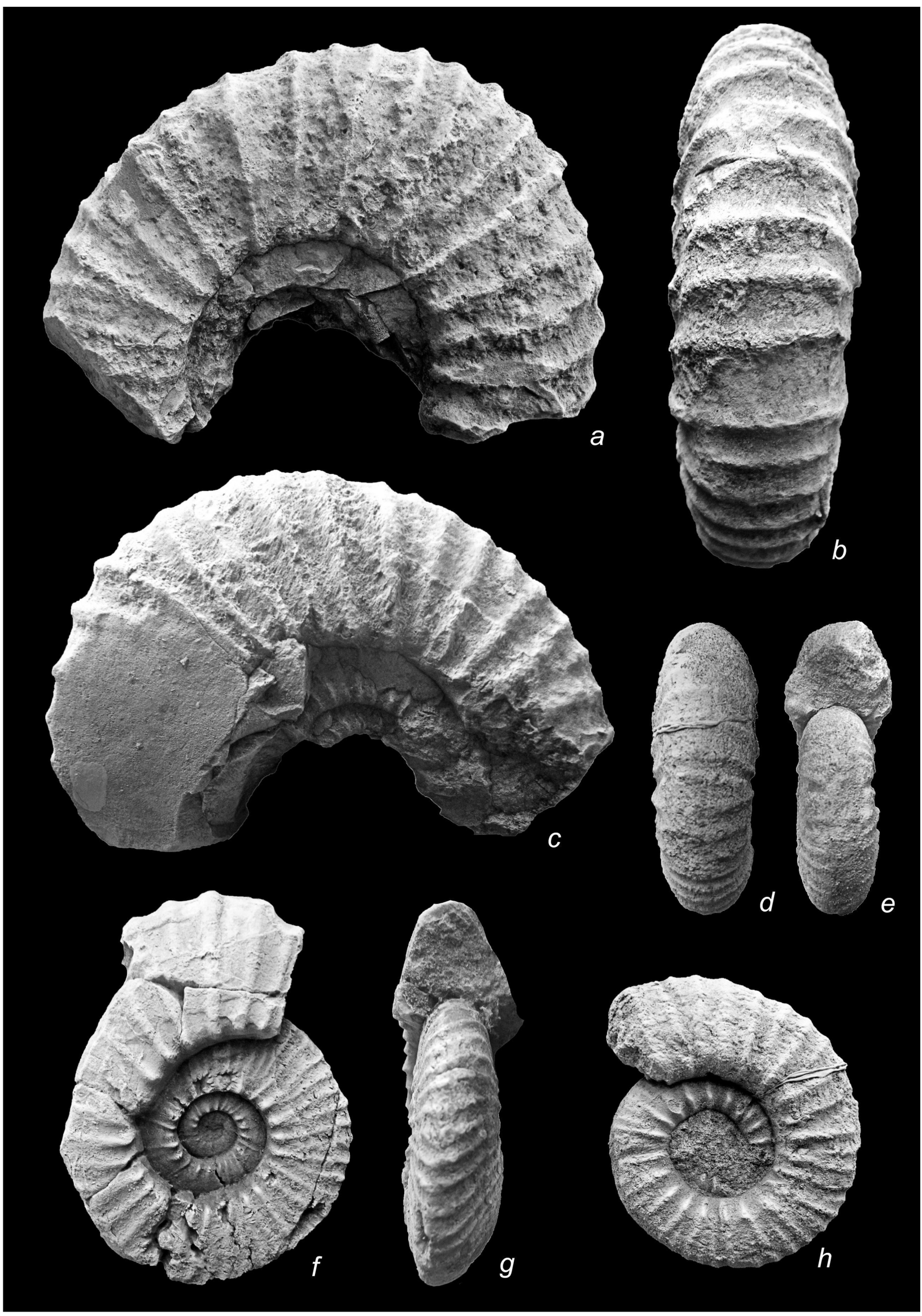


flanked by prominent sharp ribs, were observed on the cast.

Discussion. Hancock and Kennedy (1993) and Kennedy and Klinger (2013) discussed the main differences between $P$. muratovi and the other similar species of Pseudokossmaticeras. The main difference with $P$. galicianum and $P$. tercense is the lack of prominent umbilical bullae and the concave shape of the ribs in the umbilical area. Pseudokossmaticeras brandti is more evolute and has coarser ribbing. In addition, $P$. muratovi differs in having a larger number of ribs and denser ribbing, in which most of the primary ribs bifurcate high on the flanks. Occurrence. Lower Maastrichtian, Crimea and Bulgaria.

\section{Pseudokossmaticeras tercense (Seunes, 1892)}

(Fig. 3e; Fig. 4a-c, $d, g$, j, $k$; Fig. $5 a-c$; Fig. $7 a-c$; Fig. 9f, g; Fig. 10e; Fig. 11g, $h$ )

1890b. Pachydiscus af. galicianus Favre: Seunes, p. 238, Pl. 9, Fig. 5.

1892. Pachydiscus galicianus Favre sp. mut. Tercensis Seunes, p. 16, Pl. 15 (6), Fig. 4.

1894. Pachydiscus brandti Redtenbacher sp. var. Pégoti de Grossouvre, p. 194, Pl. 30, Fig. 3.

1934. Pachydiscus Galicianus Favre: Jélev, p. 198, Pl. 4, Fig. 1.

1959. Pseudokossmaticeras galicianum (Favre): Naidin and Shimansky, p. 189, Pl. 13, Fig. 1.

V 1964. Pseudokossmaticeras galicianum tercense (Seunes, 1890): Tz. Tzankov, p. 158, Pl. 6, Fig. 1; Pl. 7, Fig. 2.

V 1964. Pseudokossmaticeras galicianum (Favre, 1869): Tz. Tzankov, p. 157, Pl. 4, Fig. 1; Pl. 5, Fig. 2.

1974. Pseudokossmaticeras galicianum (Favre, 1869): Naidin, p. 179, Pl. 65, Fig. 4.

1976. Pseudokossmaticeras tercense (Seunes): Thiedig and Wiedmann, p. 18, Pl. 1, Fig. 2; Pl. 2, Fig. 2.

1986. Pseudokossmaticeras tercense (Seunes, 1892): Kennedy et al., p. 1007, Pl. 1, Figs 6, 7.

1993. Pseudokossmaticeras tercense (Seunes, 1892): Hancock and Kennedy, p. 157, Pl. 7, Figs 1-4 (Figs 3, 4 = refigured lectotype); Pl. 8, Figs 1-6.
1993. Pseudokossmaticeras tercense (Seunes, 1892): Ward and Kennedy, p. 29, Fig. 25.5.

2001. Pseudokossmaticeras tercense: Courville and Odin, Pl. 7, Figs 55-59.

2001. Pseudokossmaticeras tercense: Kennedy and Odin, Pl. 1, Figs 1, 6, 7.

2001. Pseudokossmaticeras cf. tercense: Kennedy and Odin, Pl. 1, Fig. 4.

Lectotype. The original of Seunes (1892, Pl. 15 (6), Fig. 4), from the lower Maastrichtian at Tercis (France), was designated lectotype by Kennedy et al. (1986, p. 1008). The lectotype was refigured by Hancock and Kennedy (1993, Pl. 7, Figs 3, 4). According to Hancock and Kennedy (1993, p. 157), this type specimen is also original for Pachydiscus Brandti Redtenbacher var. Pégoti de Grossouvre, and therefore the latter name is a synonym of $P$. tercense. The lectotype is housed at the Muséum national d'histoire naturelle, Paris (Cat. Nr. MNHNF-A24293).

Material and record. Ten specimens: Kladorub, Kladorub Formation (Inv.-Nr. BAS $\mathrm{Cr}_{2}$ 98, original specimen of Tz. Tzankov, 1964, pl. 5, fig. 2, refigured here in Fig. 5a-c; Inv.-Nr. BAS $\mathrm{Cr}_{2}$ 97, original specimen of Tz. Tzankov, 1964, pl. 4, fig. 1, refigured here in Fig. 7a; Inv.-Nr. BAS $\mathrm{Cr}_{2}$ 103, original specimen of Tz. Tzankov, 1964, pl. 6, fig. 1, pl. 7, fig. 2, refigured here in Figs 9f, g, 10e); Kunino, Kunino Formation (Inv.-Nrs. U.S., K 1797 and U.S., $\mathrm{K}_{2}$ 1798, this study); Reselets, Kunino Formation (Inv.-Nrs. U.S., $K_{2}$ 1802, U.S., $K_{2} 1805$, U.S., $\mathrm{K}_{2}$ 807, and U.S., $\mathrm{K}_{2} 1808$, this study); Dolna Beshovitsa, probably from the Kunino Formation (Inv.-Nr. 307, unpublished specimen of Jolkičev). Lower Maastrichtian.

Measurements. See Table 2.

Description. The early growth stages are represented by two small, moderately evolute specimens with diameters of $53 \mathrm{~mm}$ (Fig. 3e) and $45 \mathrm{~mm}$ (Fig. $4 a-c)$. The latter specimen, U.S., $\mathrm{K}_{2} 1797$, has a compressed whorl section due to post-mortem flat-

Fig. 10. Early Maastrichtian ammonites of the genus Pseudokossmaticeras from the Western Fore-Balkan Mts.: $a$, b) Pseudokossmaticeras galicianum (Favre, 1869), Inv.-Nr. U.S., K 1796 (Kunino, bed 6, Kunino Formation); c) Pseudokossmaticeras cf. galicianum (Favre, 1869), Inv.-Nr. U.S., K 1801 (Bukovets, Darmantsi Formation,); d) Pseudokossmaticeras galicianum (Favre, 1869), Inv.-Nr. $\mathrm{Cr}_{2} 1131$ (original specimen of V. Tzankov, 1982, pl. 13, fig. 3, left view; Bukovets, Kunino Formation); e) Pseudokossmaticeras tercense (Seunes, 1890), Inv.-Nr. BAS Cr 103 (original specimen of Tz. Tzankov, 1964, pl. 6, fig. 1, left view; Kladorub, Kladorub Formation. All figures are in natural size. 


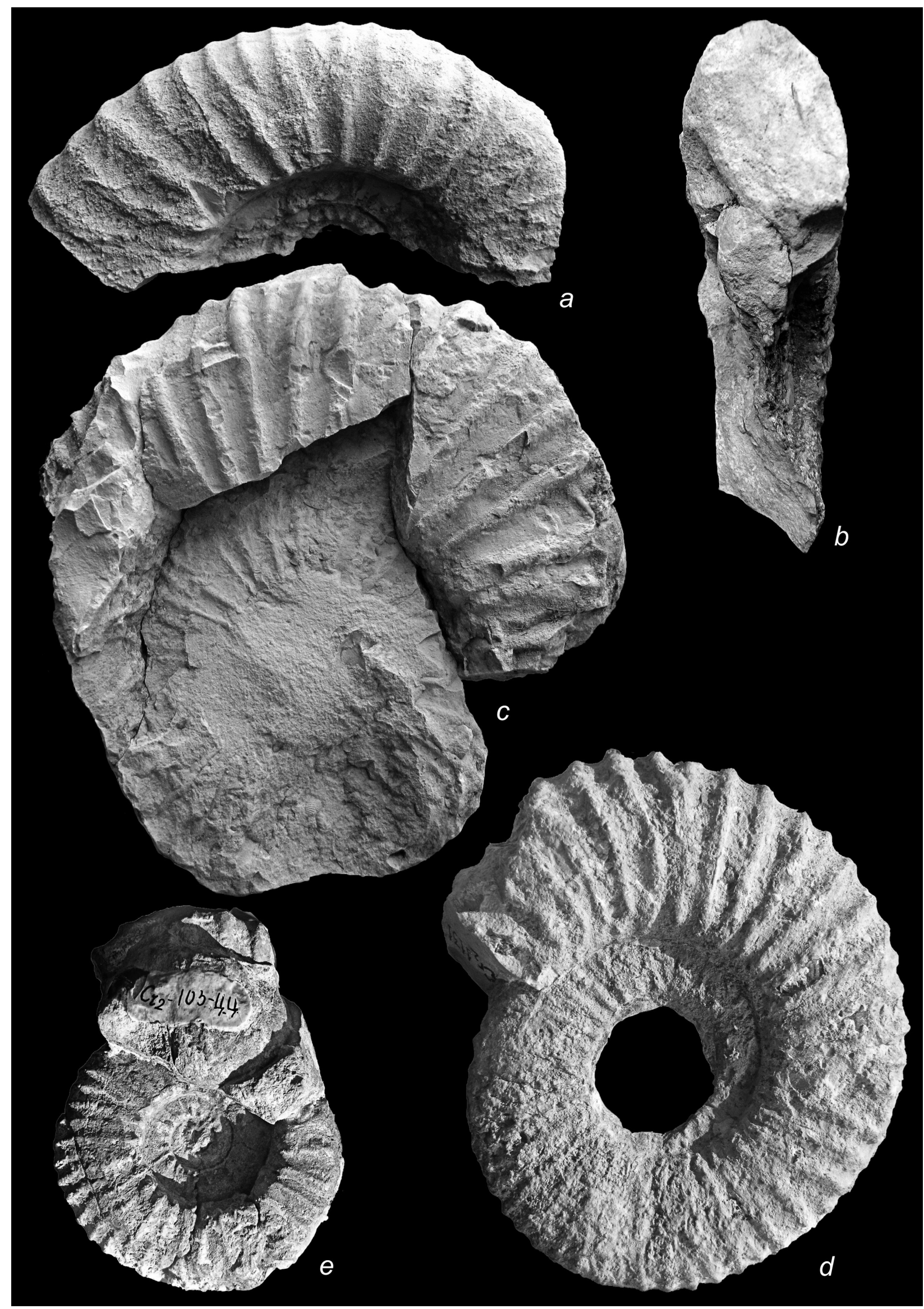




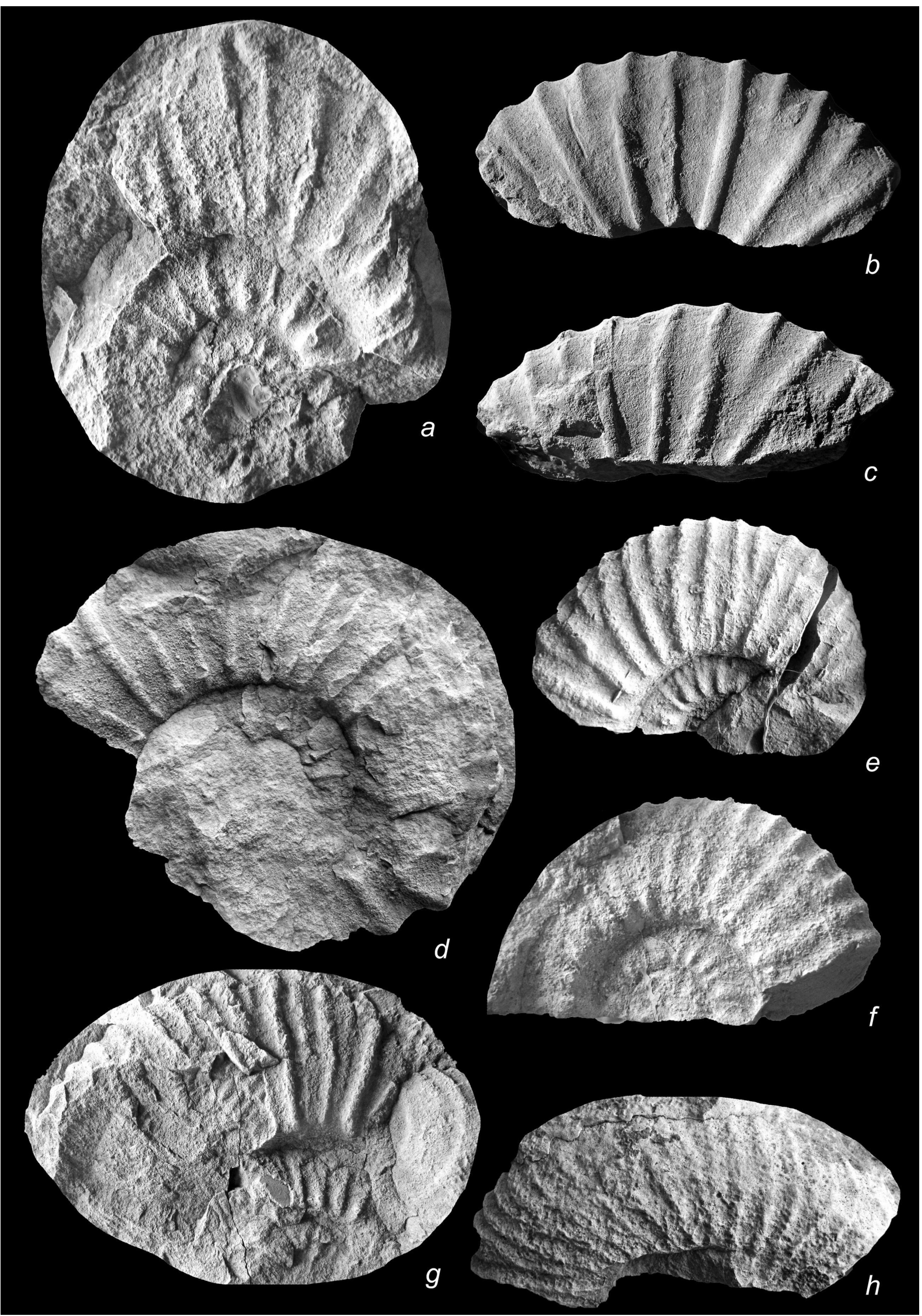


Fig. 11. Early Maastrichtian ammonites of the genus Pseudokossmaticeras from the Western Fore-Balkan Mts.: $a$, d) Pseudokossmaticeras galicianum (Favre, 1869), Inv.-Nr. 256 (unpublished specimen of Yolkichev; Kunino, Kunino Formation); b, c) Pseudokossmaticeras cf. galicianum (Favre, 1869), Inv.-Nr. 5047 (unpublished specimen of Yolkichev; Varbinka, probably from the Yankovo Formation); e, f) Pseudokossmaticeras galicianum (Favre, 1869), Inv.-Nr. 258 (unpublished specimen of Yolkichev; Kunino, Kunino Formation); g) Pseudokossmaticeras tercense (Seunes, 1892), Inv.-Nr. 307 (unpublished specimen of Yolkichev; Dolna Beshovitsa, Kunino Formation); h) Pseudokossmaticeras tercense (Seunes, 1892), Inv.-Nr. U.S., K 1808 (Reselets, bed 17 , Kunino Formation). All figures are in natural size.

tening. It has a shallow umbilicus, which is bordered by a sloping umbilical wall, and a broadly rounded umbilical shoulder. There are 20 small but sharp umbilical bullae. Narrow and sharp prorsiradiate primary ribs arise from the bullae, usually in pairs, but single ribs may also occur. Non-bullate prorsiradiate intercalatory ribs may occasionally raise low on the flanks. All ribs cross the venter. The total number of the ribs is more than 45 . Three shallow constrictions were also observed.

Specimen U.S., $\mathrm{K}_{2} 1807$ (Fig. 4j, $k$ ) is partially preserved, with a vertical umbilical wall and rounded umbilical shoulder, and differs in ornament. This specimen is also bullate, but the bullae are situated on the umbilical shoulder. The ornament is denser, with primary ribs that are straight on the flanks but concave on both the ventrolateral shoulder and the venter. Some of the intercalated ribs are lower in relief than the primaries. They arise low or in the middle part of the flanks. The total number of the ribs is 34 .

The specimens of Tz. Tzankov (1964, pl. 4, fig. 1; pl. 5, fig. 2; Figs $5 a-c, 7 a$ herein), are adults with diameters of $93.5 \mathrm{~mm}$ and $102.3 \mathrm{~mm}$, respectively. Both ammonites are compressed, with a moderately deep umbilicus, vertical umbilical wall and rounded umbilical shoulder. At sizes below $60 \mathrm{~mm}$ diameter, the ornamentation consists of dense, narrow and bullate ribs; shallow constrictions are also visible. The last preserved whorls are ornamented with sharp ribs arising from umbilical bullae. The former specimen (Fig. $5 a-c$ ) has 27 primary ribs and 17 secondaries; some of the primaries are initially slightly convex; on the flanks they become straight, and on the ventrolateral shoulder they are concave. The secondaries are usually intercalated low on to in the middle of the flanks. The ornament of the former specimen (Fig. 7a) consists of 33 prorsiradiate primary ribs and more than 17 intercalated ribs, both round-topped and straight on the flanks but flexing forwards (some sharply) on the ventrolateral shoulder.

The specimen of Tz. Tzankov (1964, pl. 6, pl. 7, fig. 2) is a near-complete moderately evolute ammonite with a diameter of $53 \mathrm{~mm}$ (see Figs $9 f, g, 10 e$ herein). The whorl section is compressed ( $\mathrm{Wb} / \mathrm{Wh}=$ 0.71 ), with flat flanks that are convergent towards a rounded venter. The umbilicus comprises $42 \%$ of the diameter and is bordered by a vertical umbilical wall and narrowly rounded umbilical shoulder. The inner whorls are finely ornamented with narrow prorsiradiate ribs arising from 25 small, sharp umbilical bullae. Four shallow constrictions are also visible. The bullae continue on the last whorl, gradually becoming rougher. On the first quarter of this whorl, each bulla gives rise to two slightly rounded prorsiradiate ribs, which are straight on the flanks and slightly concave on the ventrolateral shoulder but become slightly convex when crossing the venter. The bullae of the outermost parts of the last whorl give rise to single and flat-topped primary ribs. The rib interspaces become wider. Rare intercalated, flat to round-topped ribs also arise low on the flanks. A total of 40 ribs are developed at this stage of coiling.

Discussion. Kennedy and Summesberger (1987), Hancock and Kennedy (1993) and Kennedy and Klinger (2013) discussed the main differences in the group of closely related species of Pseudokossmaticeras with similar morphology: P. brandti, $P$. galicianum, $P$. tercense, $P$. muratovi, $P$. pacificum (Stoliczka), and P. dureri (Redtenbacher). Among these, $P$. tercense clearly differs in having compressed whorl section, with greater whorl height at the last whorl. It also differs in having densely ornamented inner whorls (with finely bullate ribs), as well as in the sculpture of the last whorl. The latter consists of primary ribs, arising either in singles 


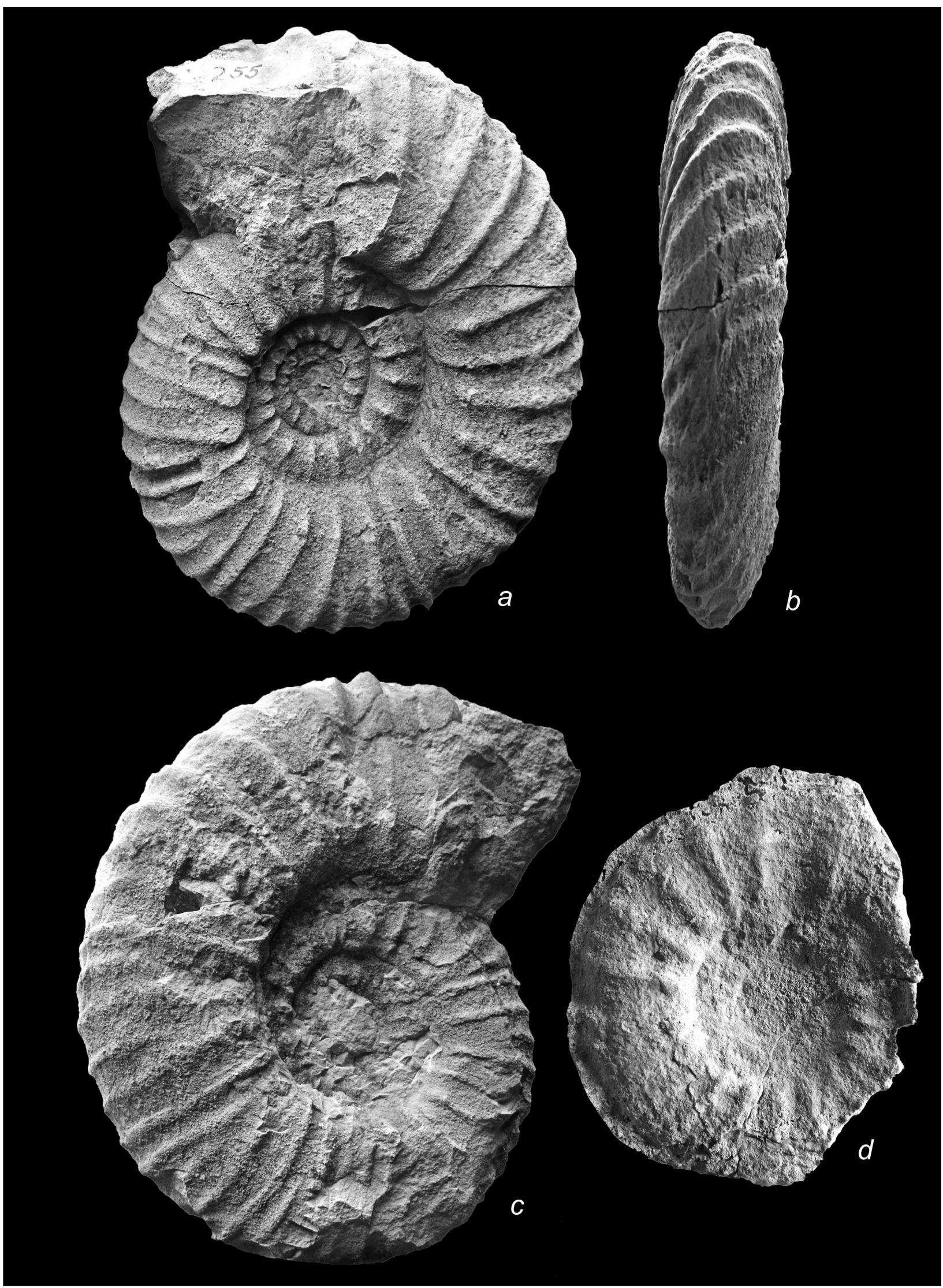




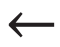

Fig. 12. Pseudokossmaticeras brandti (Redtenbacher, 1873) from the uppermost Campanian of the Western Fore-Balkan Mts.: $a-c$ ) Inv.-Nr. 255 (unpublished specimen of Yolkichev; Reselets train station and "Kuklite" area, probably from the Darmantsi Formation); d) Inv.-Nr. 242 (unpublished specimen of Yolkichev; Ralyovo, probably from the Darmantsi Formation,). All figures are in natural size.

or in pairs from sharp umbilical bullae, and secondary ribs that commonly rise low on the flanks and are differentiated from the primaries. We consider that the ornament in $P$. tercense consists of two types: 1) straight, bullate and predominantly round-topped primary ribs that bifurcate on the umbilical shoulder or low (rarely in the middle) on the flanks and also round-topped secondaries (see Fig. $4 a, b$; see also Hancock and Kennedy, 1993, pl. 8, fig. 2, 3); this ornamentation style is observed more often in immature specimens; and 2) primary ribs that are straight on the flanks but become concave on the ventrolateral shoulder and the venter; secondary ribs arise low on the flank and are clearly discernible from the primaries (e.g., Figs $4 j, 7 a$ ).

Although specimens U.S., $\mathrm{K}_{2} 1802$ (Fig. 3e) and U.S., $\mathrm{K}_{2} 1798$ (Fig. 7b, c) are incomplete, their ornament is characteristic, and thus we define them as $P$. tercense. The narrowly spaced primary ribs that arise as singles or in pairs from small umbilical bullae, and the secondary ribs that appear low on the flanks, are typical sculpture elements of $P$. tercense. Besides, the secondary ribs are differentiated from the primaries.

The specimens described as $P$. galicianum by Tz. Tzankov (1964, pl. 4, fig. 1; pl. 5, fig, 2) we reinterpret as $P$. tercense (see above; see also Figs $5 a-c, 7 a$ ). Despite being deformed, these ammonites display moderately evolute coiling, highly compressed whorl sections, and ornament, in which the lower secondary ribs differ from the primaries, i.e., typical characteristics for $P$. tercense. We note in addition that in these specimens the direction of the ribs changes on the flanks. Ribs are straight on the inner half of the flanks, and then curve forwards. This is another feature, which can be used for distinguishing $P$. tercense from $P$. galicianum (see also Kennedy et al., 1986, p. 1008).
Occurrence. According to Kennedy et al. (1986, p. 1008), the type material for $P$. tercense, from Tercis, is imprecisely dated as late Campanian. Ward and Kennedy (1993) reported P. tercense from the Campanian/Maastrichtian boundary interval and from the base of Member I (lower Maastrichtian) in the Bay of Biscay region. The occurrences from Carinthia, Austria (Thiedig and Wiedmann, 1976), and the localities of the former USSR (Naidin and Shimansky, 1959; Naidin, 1974) are from the lower Maastrichtian. The Bulgarian record is firmly from the lower Maastrichtian.

\section{CONCLUDING REMARKS}

A revision of the ammonite genus Pseudokossmaticeras from Bulgaria has been made. Based both on previously collected and new material, the following species have been identified: P. brandti (Redtenbacher, 1873); P. galicianum (Favre, 1869); P. muratovi Michailov, 1951; and P. tercense (Seunes, 1892). Due to the wide dispersal of Bulgarian localities, these species could not be defined in terms of their accurate superposition, but with the help of some coeval age-defining inoceramid taxa they were placed in an appropriate overall chronostratigraphic framework. Thus, $P$. brandti was confined to the uppermost Campanian, while the other three species were restricted to the lower Maastrichtian. From a taxonomical viewpoint, the following conclusions can be drawn for the Bulgarian examples of the genus Pseudokossmaticeras: 1) $P$. brandti stands out with the roughest ornament and the stoutest whorl section; 2) P. tercense features a compressed whorl section, which is particularly high at the last whorl, and also has densely ornamented inner whorls; 3) P. muratovi differs in lacking prominent umbilical bullae and 


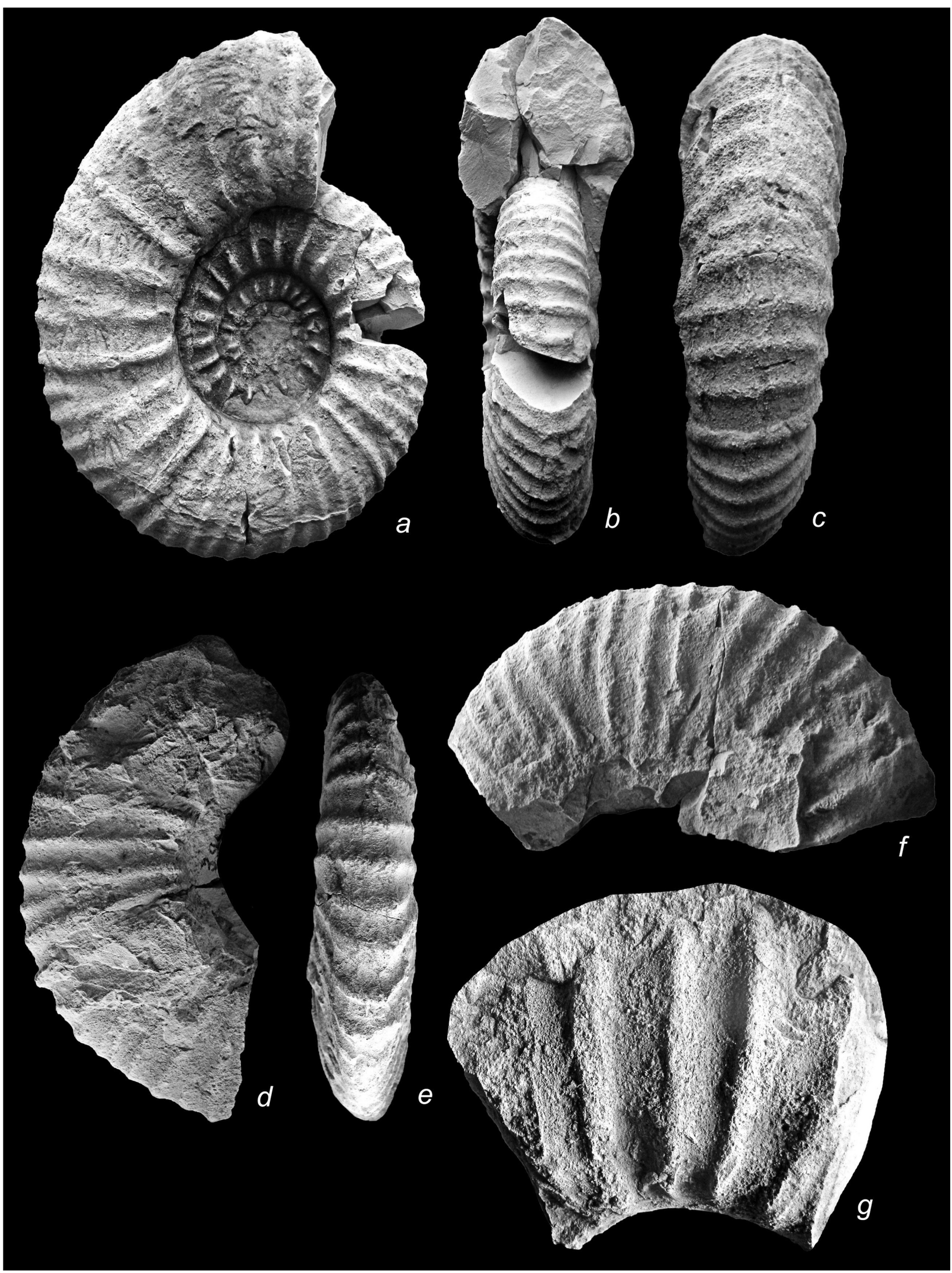




\section{$\leftarrow$}

Fig. 13. Early Maastrichtian ammonites of the genus Pseudokossmaticeras from the Western Fore-Balkan Mts.: a-c) Pseudokossmaticeras galicianum (Favre, 1869), Inv.-Nr. 254 (unpublished specimen of Yolkichev; Kunino, Kunino Formation); $d-f$ ) Pseudokossmaticeras cf. galicianum (Favre, 1869), Inv.-Nr. 3940 (unpublished specimen of Yolkichev; Dolna Beshovitsa, Kunino Formation); g) Pseudokossmaticeras cf. galicianum (Favre, 1869), Inv. Nr. 256 (unpublished specimen of Yolkichev; Kunino, Kunino Formation). All figures are in natural size.

having dense ribbing, in which most of the primary ribs bifurcate high on the flanks; 4) P. galicianum has a consistently compressed whorl section and an ornament which is composed of equally pronounced primary and secondary ribs.

\section{Acknowledgements}

We will always be immensely grateful to the late Prof. Nikola Jolkičev, who kindly guided and en- couraged us and who generously loaned his material to be entirely available. Warm thanks are expressed to Prof. William James Kennedy (Oxford University Museum of Natural History, UK) and Prof. Elena Jagt-Yazykova (University of Opole, Poland) for much-appreciated constructive criticism. Dr. John W.M. Jagt (Natuurhistorisch Museum Maastricht) is greatly acknowledged for his help in improving the language construction of the manuscript.

\section{REFERENCES}

Arkadiev, V.V., Atabekian, A.A., Baraboshkin, E.Y., Bogdanova, T.N. 2000. Stratigraphy and ammonites of Cretaceous deposits of South-west Crimea. Palaeontographica A 255 (4-6), 85-128.

Błaszkiewicz, A. 1980. Campanian and Maastrichtian ammonites of the Middle Vistula River valley, Poland: a stratigraphic-paleontological study. Prace Instytutu Geologicznego 92, 1-63.

Böhm, J. 1927. Beitrag zur Kenntnis der Senonfauna der Bithynischen Halbinsel. Palaeontographica 69, 187-222.

Collignon, M. 1938. Ammonites Campaniennes et Maestrichtiennes de l'ouest et du sud de Madagascar. Annales Géologiques du Service des Mines de Madagascar 9, 55-118.

Courville, P., Odin, G.S. 2001. Les ammonites spiralées du Campanien et du Maastrichtien de Tercis les Bains (Landes, France). In: Odin, G.A. (Ed.), The CampanianMaastrichtian Stage Boundary. Characterization at Tercis les Bains (France) and Correlation with Europe and other Continents. Elsevier, Amsterdam, 529-549, https://doi. org/10.1016/S0920-5446(01)80053-4.

Dabovski, H., Kamenov, B., Sinnyovsky, D., Vasilev, E., Dimitrova, E., Bayraktarov, I. 2009. Upper Cretaceous geology. In: Zagorchev, I., Dabovski, Ch., Nikolov, T. (Eds), Geology of Bulgaria. Vol. II. Mesozoic geology. "Prof. Marin Drinov” Academic Press, Sofia, 303-589 (in Bulgarian, with English abstract).

de Grossouvre, A. 1894. Recherches sur la craie supérieure. Partie 2. Paléontologie. Les ammonites de la craie supérieure. Mémoires pour servir à l'explication Géologique détaillée de la France. Imprimerie Nationale, Paris, 264 pp., https://doi.org/10.5962/bhl.title.46845.

Dochev, D. 2012. First evidence for distribution of Maastrichtian inoceramid bivalves in the Yankovo Formation from the East Fore-Balkan (Bulgaria). Bulgarian Geological Society, National Conference with International Participation "Geosciences 2012", Abstracts, 79-80.

Dochev, D., Metodiev, L. 2020. Inoceramid bivalves from the Maastrichtian of the Western Fore-Balkan Mts (Bulgaria). Geologica Balcanica 49 (1), 31-52, https://doi. org/10.52321/GeolBalc.49.1.31.

Dochev, D., Pavlishina, P., Petkanska, I., Vladimirova, E. 2018. Preliminary results about the Campanian/Maastrichtian boundary in Reselets Section (Western Fore-Balkan) based on inoceramid bivalves, ammonites and dinoflagellate cysts. Review of the Bulgarian Geological Society 79 (3), 87-88.

Donovan, S.K., Draper, G. 2001. Further fossil cephalopods from Jamaica. Paläontologische Zeitschrift 75, 17-21, https://doi.org/10.1007/BF03022594.

d’Orbigny, A. 1842-47. Paléontologie Française. Terrains Crétacés. Lamellibranches. Baillière, Paris, 807 pp.

Douglas, R.J. 1942. New species of Inoceramus from the Cretaceous Bearpaw Formation. Transactions of the Royal Society of Canada 4, 59-65.

Favre, E. 1869. Description des mollusques fossiles de la craie des environs de Lemberg en Galicie. H. Georg, Genève, $187 \mathrm{pp}$.

Granchovski, G. 2019. Calcareous nannofossils from the Campanian-Maastrichtian (Upper Cretaceous) in the Kladorub 
Formation (Kula tectonic zone, NW Bulgaria). Geologica Balcanica 48 (1), 73-101, https://doi.org/10.52321/Geol Balc.48.1.73.

Hancock, J.M., Kennedy, W.J. 1993. The high Cretaceous ammonite fauna from Tercis, Landes, France. Bulletin de l'Institut Royal des Sciences Naturelles de Belgique, Sciences de la Terre 63, 149-209.

Hauer, F. von. 1858. Über die Cephalopoden des Gosauschichten. Beiträge zur Paläontologie von Österreich 1, 7-14.

Ivanov, Ž. 2017. Tectonics of Bulgaria. Sofia University Press, Sofia, 331 pp. (in Bulgarian, with English abstract).

Jélev, S.T. 1934. Géologie des environs de Pléven. II. Paléontologie. Review of the Bulgarian Geological Society 6 (3), 166-203 (in Bulgarian, with French abstract).

Jolkičev, N.A. 1986. Lithostratigraphic units related to the Upper Cretaceous in the West and Central Fore-Balkan. Review of the Bulgarian Geological Society 47 (3), 49-61 (in Bulgarian, with English abstract).

Jolkičev, N.A. 1989. Stratigraphy of the epicontinental type Upper Cretaceous in Bulgaria. "Kliment Ohridski” University Press, Sofia, 184 pp. (in Bulgarian, with Russian and English abstracts).

Jolkitschev, N., Vapzarova, J. 1967. Über die Anwesenheit der Campanichen Stufe in Vorbalkan zwischen dem Skât-und Katunetzkafluss. Annuaire de l'Université de Sofia 61 (1), 81-102 (in Bulgarian, with German abstract).

Kennedy, W.J., Bilotte, M. 1995. A new ammonite fauna from the Sub-Pyrenean Campanian (Upper Cretaceous). Geobios 28 (3), 359-370, https://doi.org/10.1016/S00166995(95)80011-5.

Kennedy, W.J., Cobban, W.A. 1993. Ammonites from the Saratoga Chalk (Upper Cretaceous), Arkansas. Journal of Paleontology 67 (3), 404-434, https://doi.org/10.1017/ S002233600003688X.

Kennedy, W.J., Bilotte, M., Lepicard, B., Segura, F. 1986. Upper Campanian and Maastrichtian ammonites from the Petites-Pyrenees, southern France. Eclogae Geologicae Helvetiae 79 (3), 1001-1037.

Kennedy, W.J., Bilotte, M., Morala, A. 2001. Pseudokossmaticeras brandti Redtenbacher, 1873, an Upper Campanian marker fossil in northern Aquitaine France. Cretaceous Research 22 (2), 259-262, https://doi.org/10.1006/ cres.2001.0246.

Kennedy, W.J., Klinger H.C. 2013. Cretaceous faunas from Zulu Land and Natal, South Africa. New records of Maastrichtian ammonites of the Family Kossmaticeratidae. African Natural History 9, 55-60.

Kennedy, W.J., Odin, G.S. 2001. Report on a preliminary blind test on ammonites collected from Tercis les Bains (Landes, France). In: Odin, G. A (Ed.), The CampanianMaastrichtian Stage Boundary, Characterization at Tercis les Bains (France) and Correlation with Europe and other Continents, Elsevier, Amsterdam, 478-482, https://doi. org/10.1016/S0920-5446(01)80049-2.

Kennedy, W.J., Summesberger, H. 1987. Lower Maastrichtian Ammonites from Nagoryany (Ukrainian SSR). Beiträge zur Paläontologie von Österreich 13, 25-78.

Kennedy W.J., Summesberger, H. 1991. A note on the lectotype of Ammonites galicianus Favre, 1869. Annalen des Naturhistorischen Museum in Wien 92, 93-95.

Khalafova, R.A. 1969. Fauna and stratigraphy of the Upper Cretaceous deposits of the SE part of the Minor Caucasus and Nachitchewan area of ASSR. Azerbaijan Academy of Sciences State Publisher, Baku, 330 pp. (in Russian).
Küchler, T., Kurtz, A., Wagreich, M. 2001. The CampanianMaastrichtian boundary in northern Spain (Navarra province): the Imiscoz and Erro sections. In: Odin, G. A (Ed.), The Campanian-Maastrichtian Stage Boundary, Characterization at Tercis les Bains (France) and Correlation with Europe and other Continents. Elsevier, Amsterdam, 723-744, https://doi.org/10.1016/S0920-5446(01)80064-9.

Mariani, E. 1898. Ammoniti del Senoniano Lombardo. Memorie dell'Istituto Lombardo di Scienze e Lettere. Classe di Scienze Matematiche e Naturali 3 (18), 51-58.

Martinez, R. 1997. Campanian and Maastrichtian ammonites from southern Spain. Cretaceous Research 18 (3), 373384, https://doi.org/10.1006/cres.1997.0066.

Meek, F.B. 1876. A report of the invertebrate Cretaceous and Tertiary fossils of the upper Missouri country. Geological Survey of the Territories (Hayden) Report 9, 629 pp.

Michailov, N.P. 1951. Upper Cretaceous ammonites from the southern European part of the USSR and their importance for zonal stratigraphy (Campanian, Maastrichtian). Trudy Instituta Geologicheskich Nauk Akademii Nauk SSSR 50 (129), 143 pp. (in Russian).

Morton, S.G. 1834. Synopsis of the organic remains of the Cretaceous group in the United States. Key and Biddle, Philadelphia, 1-88, https://doi.org/10.5962/bhl.title.59206.

Naidin, D.P. 1974. Cephalopods. In: Krymgolts, G.Y. (Ed.), Atlas of the Upper Cretaceous fauna of the Donbas. Nedra, Moscow, 158-240 (in Russian).

Naidin, D.P., Shimansky, V.N. 1959. Cephalopoda. In: Moskvin, M.M. (Ed.), Atlas of the Upper Cretaceous fauna of the northern Caucasus and Crimea. Gostoptekhtizdat, Moscow, 166-220 (in Russian).

Pavlishina, P., Dochev, D., Metodiev, L., Vladimirova, E. 2020. Inoceramid bivalves and dinoflagellate cysts integrated biostratigraphy of the topmost Campanian-Maastrichtian in part of the Western Fore-Balkan Mountains, northwest Bulgaria. Geologica Balcanica 49 (3), 39-63, https://doi. org/10.52321/GeolBalc.49.3.39.

Pethö, J. 1906. Die Kreide (Hypersenon-) Fauna des Peterwardeiner (Petervarder) Gebirges (Fruska Gora). Palaeontographica 52, 57-336.

Redtenbacher, A. 1873. Die Cephalopodenfauna der Gosauschichten in den nordöstlichen Alpen. Abhandlungen der Kaiserlich-Königlichen Reichsanstalt 5, 91-140.

Reyment, R. 1958. Neubeschreibung der Redtenbacher'schen Ammonitenoriginale aus den Gosauschichten. Acta Universitatis Stockholmiensis - Stockholm Contributions in Geology 2, 31-49.

Salaj, J., Wiedmann, J. 1989. The Campanian-Maastrichtian boundary in the El Kef section, Tunisia. In: Wiedmann, J. (Ed.), Cretaceous of the Western Tethys. E. Schweizerbart'sche Verlagsbuchhandlung, Stuttgart, 299315.

Schlüter, C. 1872. Cephalopoden der oberen deutschen Kreide. Palaeontographica 21, 1-120.

Seunes, J. 1890a. Contribution à l'étude des céphalopodes du Crétacé Supérieur de France. Mémoires de la Société Géologique français de Paléontologie 2, 1-22.

Seunes, J. 1890b. Recherches géologiques sur les terrains secondaires et l'Éocène inférieur de la région sous-pyrénéenne du sud-ouest de la France (Basses-Pyrénées et Landes). Dunod, Paris, 250 pp.

Seunes, J. 1892. Contributions à l'étude des céphalopodes du Crétacé Supérieur de France. I. Ammonites du Calcaire à Baculites du Cotentin (Suite). II. Ammonites du Campanien de la région sous-pyrénéenne. Département de Landes. Mé- 
moires de la Société Géologique français de Paléontologie 2, 9-22.

Sinnyovsky, D. 2013. Upper Cretaceous calcareous nannoplankton biostratigraphy in Bulgaria. "St Ivan Rilski” Publishing House, Sofia, 81 pp.

Sinnyovsky, D., Marinova, R., Jelev, V. 2012. Upper Cretaceous lithostratigraphy in the West Srednogorie. Part 1. Review of the Bulgarian Geological Society 73 (1-3), 105-122.

Sinnyovsky, D., Marinova, R., Jelev, V. 2013. Upper Cretaceous lithostratigraphy in the West Srednogorie. Part 2. Review of the Bulgarian Geological Society 74 (1-3), 65-79.

Sinnyovsky, D., Vangelov, D. 2007. Stratigraphy of the Upper Cretaceous-Paleocene deposits along the southern rim of the Provadia Plateau in Golyama Kamchia River defile. Review of the Bulgarian Geological Society 68 (1-3), 23-35 (in Bulgarian).

Spath, L. F., 1922. On the Senonian ammonite fauna from Pondoland. Transactions of the Royal Society of Africa 10 (1), 113-147, https://doi.org/10.1080/00359192209519274.

Stoliczka, F. 1865. The Fossil Cephalopoda of the Cretaceous Rocks of Southern India. Memoirs of the Geological Survey of India, Palaeontologia Indica, 41-216.

Summesberger, H., Wagreich, M., Tröger, K.A., Scholger, R. 2002. The Upper Cretaceous in Piesting (Austria): Integrated stratigraphy of the Piesting Formation (Gosau Group): In Wagreich, M. (Ed.), Aspects of Cretaceous Stratigraphy and Palaeobiogeography. Schriftenreihe der Erdwissenschaftlichen Kommission, Österreichische Akademie der Wissenschaften 15, 373-399.

Summesberger, H., Zorn, I.A. 2012. Catalogue of type specimens of Late Cretaceous cephalopods housed in the collections of the Geological Survey of Austria in Vienna. Jahrbuch der Geologischen Bundesanstalt 152 (1-4), 101-144.

Thiedig, F., Wiedmann, J. 1976. Ammoniten und Alter der höheren Kreide (Gossau) des Krappfeldes in Kärnten (Österreich). Mitteilungen aus dem Geologisch-Paläontologischen Institut der Universität Hamburg 45, 9-27.

Tzankov, Tz. 1964. Ammonites from the Maastrichtian near Kladorub village Belogradchik region (North-western Bulgaria). Travaux sur la Géologie de Bulgarie, Série Paléontologie 6, 143-168 (in Bulgarian, with Russian and English abstracts).

Tzankov, V. 1935. Quelques céphalopodes fossiles sénoniennes de la Bulgarie du Nord. Review of the Bulgarian Geological Society 7 (1), 8-14 (in Bulgarian, with French abstract).

Tzankov, V. 1982. Les fossiles de Bulgarie. Va. Crétacé supérieur. Cephalopoda (Nautiloidea, Ammonoidea) et Echi- nodermata (Echinoidea). Académie Bulgare des sciences, Sofia, 125 pp. (in Bulgarian, with French abstract).

Tzankov, V., Dimitrova, H., Stephanov, J., Vrablyanski, B. 1960. Recherches stratigraphiques sur le jurassique et le crétacé dans la Bulgarie du nord-ouest. Travaux sur la géologie de Bulgarie, Série stratigraphie et tectonique 1, 203-241 (in Bulgarian, with French summary).

Vaptzarova, Y. 1965. Stratigraphy of the Upper Cretaceous in central North and Northwest Bulgaria based on micropaleontological data. Annual of the Head Office of Geology 15, 125-161 (in Bulgarian).

Walaszczyk, I. Cobban, W.A., Harries, P.J. 2001. Inoceramids and inoceramid biostratigraphy of the Campanian and Maastrichtian of the United States Western Interior Basin. Revue de paléobiologie 20 (1), 117-234.

Walaszczyk, I., Odin, G.S., Dhondt, A.V. 2002. Inoceramids from the Upper Campanian and Lower Maastrichtian of the Tercis section (SW France), the Global Stratotype Section and Point for the Campanian-Maastrichtian boundary; taxonomy, biostratigraphy and correlation potential. Acta Geologica Polonica 52 (3), 269-305.

Walaszczyk, I., Smirnov, J.P., Tröger, K.A. 1996. Trochoceramid bivalves (Inoceramidae) from the Lower Maastrichtian of Dagestan (Aimaki section, NE Caucasus) and south-central Poland. Acta Geologica Polonica 46 (1-2), 141-164.

Ward, P.D., Kennedy, W.J. 1993. Maastrichtian Ammonites from the Biscay Region (France, Spain). Journal of Palaeontology 67 (S34), 1-58, https://doi.org/10.1017/ S0022336000062223.

Ward, P.D., Orr, W. 1997. Campanian Maastrichtian ammonite and planktonic foraminiferal biostratigraphy from Tercis, France: implications for defining the stage boundary. Journal of Palaeontology 71 (3), 407-418, https://doi. org/10.1017/S0022336000039433.

Whitfield, R.P. 1880. Paleontology of the Black Hills of Dakota. In: Newton, H., Jenney, W.P (Eds), Report on the Geology and Resources of the Black Hills of Dakota. United States Geographical and Geological Survey of the Rocky Mountain Region, 325-468.

Yamnichenko, I.M., Astachova, T.V. 1984. Jurassic and Cretaceous Mollusca from Ukraine. Paleontological handbook. Institute for Geological Sciences at the Ukrainian SSR Academy of Sciences, Naukova dumka, Kiev, 104 pp. (in Russian).

Zlatarski, G. 1905. La série supercrétacée dans la Bulgarie centrale et occidentale, au nord des Balkans. Annuaire de l'Université de Sofia 1, 84-102 (in Bulgarian, with French summary). 